\title{
白鉄の黑鉛化に關する新現象と其黑心 可鍛鑄物工業への應用に就て
}

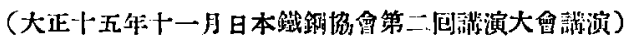

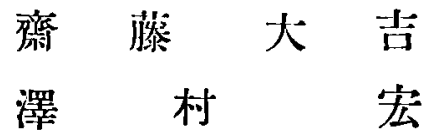

目次

\begin{tabular}{|c|c|}
\hline 緒 & \\
\hline 第一龺 白 & 䠲の黑跺化に開す万新現象の理論的考察 \\
\hline 第一節 & 研究の方法 \\
\hline 第二節 & $\begin{array}{l}\text { 白銥と一定速度にて加整せろ埧合に現は } \\
\text { 万万新現象の研究 }\end{array}$ \\
\hline 第一項 & 察䛗の力法 \\
\hline 第二椇 & 急冷眇度の影萑 \\
\hline 第三项 & 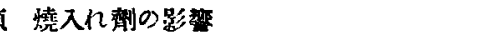 \\
\hline 第四項 & 絽り返し燒入んの影䍃 \\
\hline 第三三箅 & $\begin{array}{l}\text { 白銑か一定盢度にて加热さ万場合に現は } \\
\text { 万ろ新見象の研究 }\end{array}$ \\
\hline 第一項 & 低驗の方法 \\
\hline 第二项 & 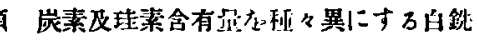 \\
\hline
\end{tabular}

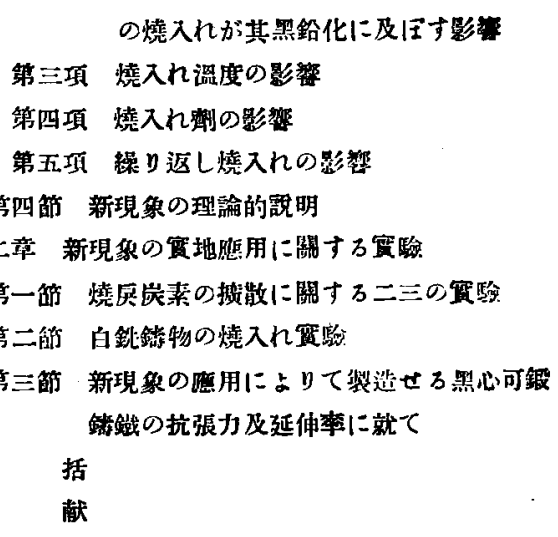

\section{緒言}

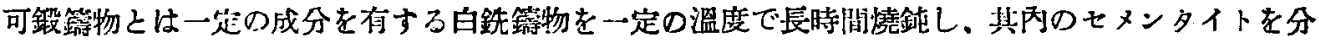
解し總ての炭素を燒㞍炭素の狀態に變じて之に可鉔性を與へたものである。而して從來發表された歐 米の之に關する學術的研究は、多くは定性的のものであつたのであるが最近本邦に於て之に關する有 益なる二論交が發表された。其一は本作 4 月金屬の研究(1)及東北大學理科報告(2)心發表された菊田 博士の諭文で他は大正 13 年 3 月以來敕司に互つて水曜會誌(3) に發表され、又本年 9 月京都大學 工學部紀要(4)に揭载された著者の論文である。兩者とも主として本多博士の熱膨脹測定器を朋ひ定量

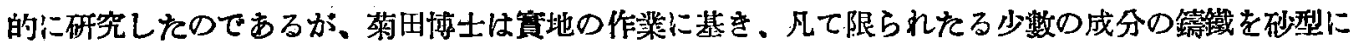

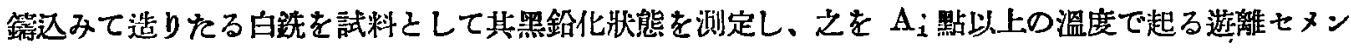
タイトの分解と $\mathrm{A}_{1}$ 點以下の溫度で起るパーライト、セメンタイトの分解との 2 つ分ち、前者を第

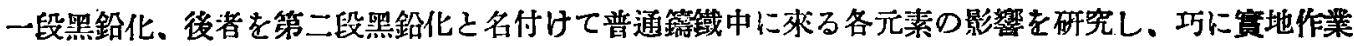
乙結付けて說明して居る。文著者は白銑の黑鉛化に對し鐵に開係ある殆んどあらゆる元素の影響を研 究し同時に白鉄の㠜固速度が其照鉛化に著しき關係ある事を明にした。而して著者は種ヶの成分の銀

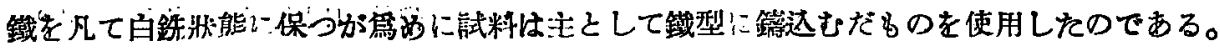


白銑の黑鉛化に關する新現象と其黑心可鍛鉆物工業への哕朋に就て 1007

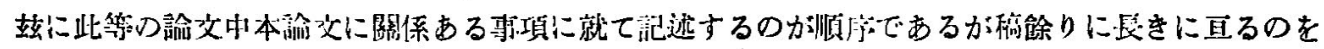
怖れて之を省略する。

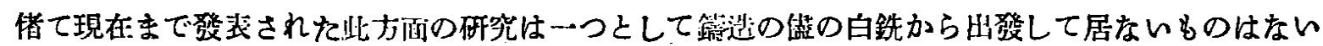
のであるが、著者は新しく橴鈍前に於ける白銑の熱所理が其㫮鉛化に如何なる關係あるかを研究し始

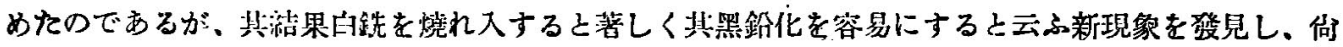

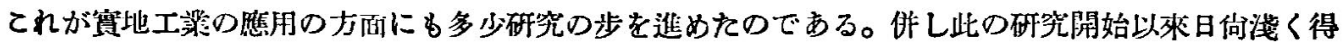

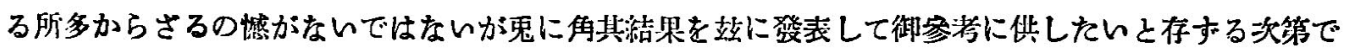
ある。

\section{第一草 白鉄の黑鉛化に關する新現象の理論的考察 \\ 第一管 研 究 の 方 法}

本孪に於て述べる筫驗に於ては白銑の熙鉛化の進行狀熊を正確に知る爲めに前研究に於りると同し

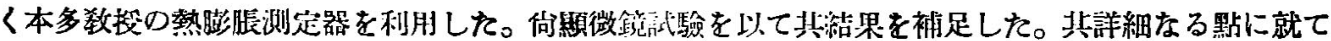
は其場合場合に說朋する事とする。

\section{第二䈱 白鉄を一定速度にて加熱せる場合に現はるる新現象の研究 第一颃寅方法}

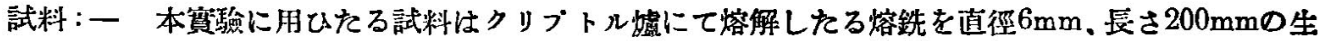

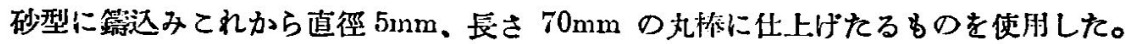

急冷方法：一 試料の急冷には Fig. 1 に示す梯な裝置を用ひた。試料を圖に示す如く電氣爐內に

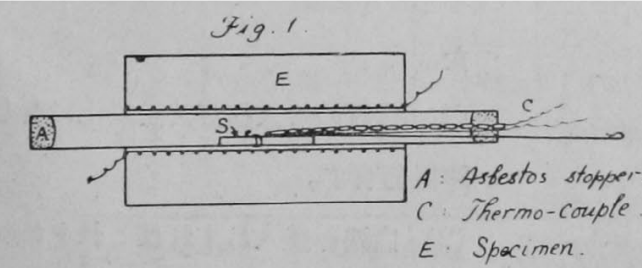

置を每分 $20^{\circ} \mathrm{C}$ なる加熱速度にて其溫度を上げ所 要の溫度に迬するや否や試料を急速に纑外に取り 出し.直ちに 500c.c. の容量のビーカー內に滿し たる燒入れ娜の中心投入急喻した。 加熱及冷却方法：一 本䁈驗に於ては特别の場

合を除き凡て旬分 $10^{\circ} \mathrm{C}$ なる一定加熱速度にて一定溫度迄加熱したる後直ちに爐中冷却した。此間、熱 膨脹測定器の蓝を密閉し其內部と外氣とを完全に遮斷して是く事とした。

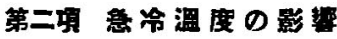

前述の方法で試料を種くの溫度功 $15^{\circ} \mathrm{C}$ の水中に急椧したる後熱膨脹测定器によつて加熱し．急 冾溫度が白鉄の黑鉛化に及法す影響を調查した。賽驗に用ひた試料の成分は Table 1 に示してある。 急椧溫度は Tablę 2 に示す如くである。Fig. 2 は此實驗の結果を表はす。圆に於て急椧溫度が $\mathrm{A}_{1}$ 點 以上なるるのに限り約 $200^{\circ} \mathrm{C}$. 及 $500^{\circ} \mathrm{C}$ 附近に於て二段の收縮の存在を示すは不多呚接 (5)によつて

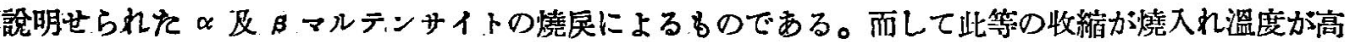

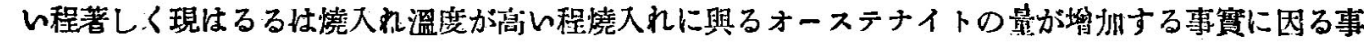


は勿解でゅる。

Table 1.

\begin{tabular}{|c|c|c|c|c|c|c|}
\hline \multirow{2}{*}{$\begin{array}{c}\text { Specimen } \\
\text { No. }\end{array}$} & \multicolumn{6}{|c|}{ Composition } \\
\cline { 2 - 7 } & $\mathrm{C}$ & $\mathrm{Si}$ & $\mathrm{Mn}$ & $\mathrm{P}$ & $\mathrm{S}$ & $\mathrm{Cu}$ \\
\hline $\mathrm{A}$ & $2 \cdot 14$ & $1 \cdot 42$ & $0 \cdot 34$ & 0.094 & $0.05 \mathrm{~s}$ & 0.23 \\
\hline
\end{tabular}

Table 2.

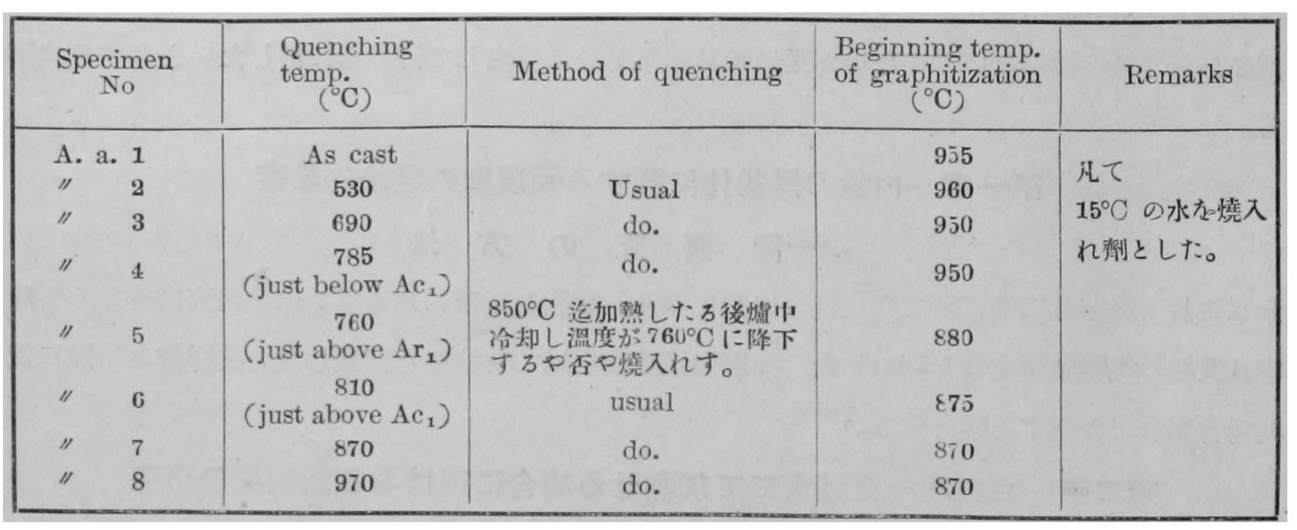

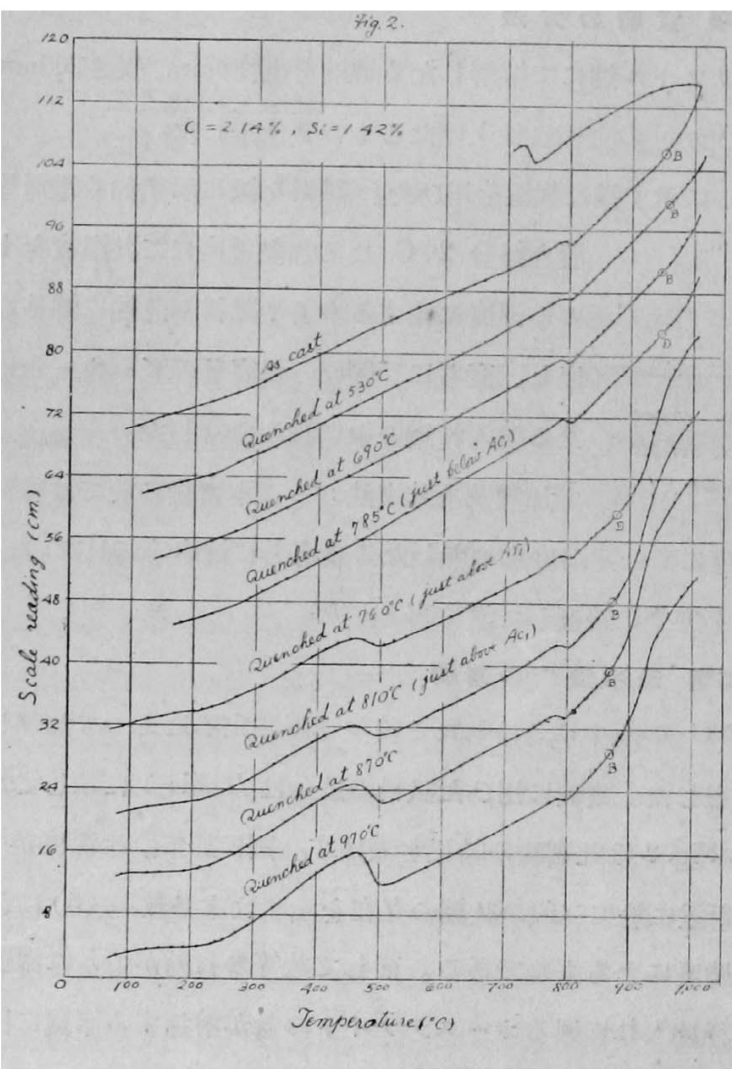

此绝の曲線に就て 黑祉化開始溫度を

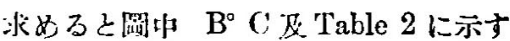
如くである。

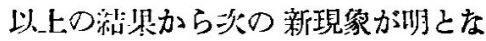
つた。

（1）白銑の燒人れが其留鉛化に著し い關係䘮准す。

（2）白銑家筧入れすればてれを燒鈍 するに當り，斯る整所理を加へさるる のに比して遥に容易に黑鉛化するすの である。

（3）白銑の燒入引溫度力滈湿其黑 鉛化は容易となるが其影㗽は著しくは ない。

沃に上の現象を毀微簛組䋨學的に觀

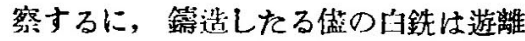
セメンタイト及パーライトよりなり 
白鉄の黑鉛化に關する新現象と其黑心可鍛鎆物工菜への應用に就て 1009

Photo. 5 に類似の組織であるが，てれを烛人れすればパーライトの部分がオーステナイト乃至マルテ ンサイトに變化する。併してれ等性㜔入れ白銑を焼鈍する際一旦パーライト（トルースタイト及ンル バイトを含む）に變化して後白銑の黙鉛化開始前に其一部文は全部は再びオーステナイトに變化した

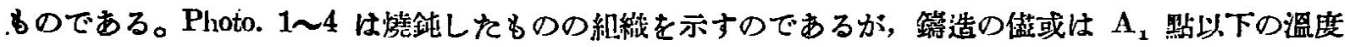
から急冷して後燒鈍せるものの組織と $\Lambda_{1}$ 默以上の溫度から燒入れして後燒鈍したるものの組織と著 しく異る事が明に知られる。郎ち前者に於ては Photo. 1 及 2 に示す如くパーライト基質內に晌多量 の遊離セメンタイトが殘留して品鉛化の非行が困難であつた事を示して居るのに反し，後者にあつて は Photo. 3 及 4 に示す如くフェライト基質內に多少のパーライトを合み遊離セメンタイトは全く存 在して居ない。此場合には黑鉛化は極めて容易に進行したのである。向てれ等の䛈微鏡組轼から試料

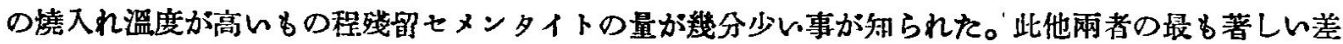
違は前者にあつては焼民炭素は小数の大きな，丸味を酎びた形となつて多くの場合オーステナイト基 質內に出來て居るが，後者にあつては多くの埸合遊篗セメンタイトがらめて居た仿通に多数の小さ

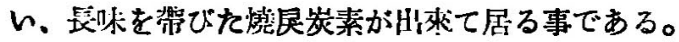

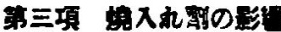

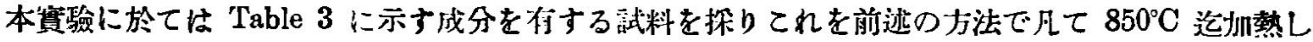
Table 3.

\begin{tabular}{|c|c|c|c|c|c|c|}
\hline Specimen & \multicolumn{5}{|c|}{ Composition (\%) } \\
\cline { 2 - 5 } & $\mathrm{C}$ & $\mathrm{Si}$ & $\mathrm{Mn}$ & $\mathrm{P}$ & $\mathrm{S}$ & $\mathrm{Cu}$ \\
\hline No. & $2 \cdot 13$ & 130 & 0.33 & 0.096 & 0.053 & 0.23 \\
\hline
\end{tabular}

Tabls 4 .

\begin{tabular}{|c|c|c|c|c|}
\hline $\begin{array}{l}\text { Specimen } \\
\text { No. }\end{array}$ & $\begin{array}{l}\text { Quenching } \\
\text { Medium }\end{array}$ & $\begin{array}{l}\text { Temp of quenching } \\
\text { medium } \\
\left({ }^{\circ} \mathrm{C}\right)\end{array}$ & $\begin{array}{l}\text { Beginning temp } \\
\text { of graphitization } \\
\left({ }^{\circ} \mathbf{C}\right)\end{array}$ & Remarks \\
\hline$M-1$ & 令 臨水 & -10 & 960 & $\begin{array}{l}\text { 凡て } \\
\text { 燒入溫度 : }\end{array}$ \\
\hline " 2 & 水 & 17 & 910 & $850^{\circ} \mathrm{C}$ \\
\hline " 3 & 水 & 80 & 910 & \\
\hline " 4 & 荣種 油 & 17 & 930 & \\
\hline
\end{tabular}

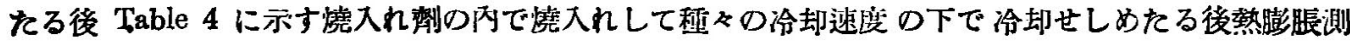
定器によつて其墨鉊化狀態を测定した。其絬果は Fig. 3 に示してある。てれから各試料の黑鉛化 開始溫度を求めると㘣中 $\mathrm{B}{ }^{\circ} \mathrm{C}$ 及 Table 4 に示す如くなる。又燒鈍せる試料の組織を检鏡せるに何

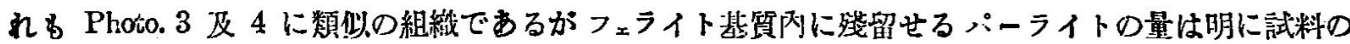



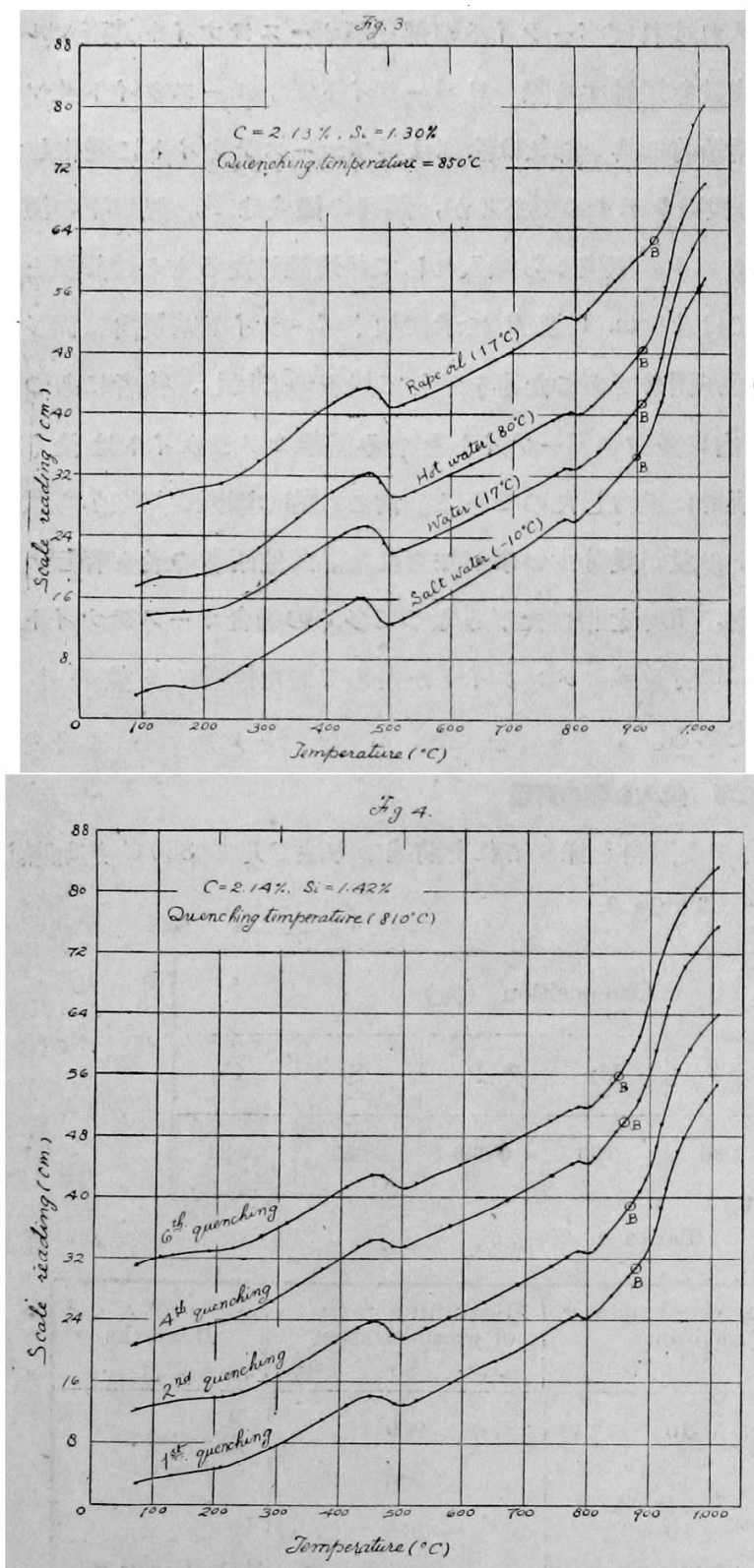

椧却速度が大なるもの程小である事を示し to

以上の宦驗絬果による之蝰入れの際街料 の渝却速度が大なる程之を㷪䣄するに當り 其哭鉛化が容易となる傾间が認められる が，此筫驗に於りる程度の椧却速度の差は

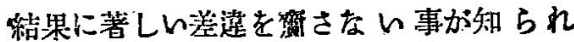
る。

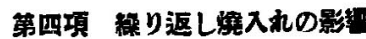

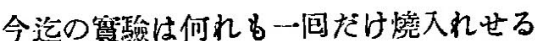
白鉄に就て行つたのであるが，同じ武料に

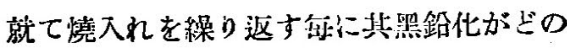
程度迄容易になり得るものであるかは興昧 ある間題となる。そてで此筧驗に於ては Specimen No. A t 4 本採り之を前述の燒 入れ方法によつてすへて $810^{\circ} \mathrm{C}$ から $15^{\circ} \mathrm{C}$ の水中に 'Table 5 に示す如き所要の回數 だけ燒入れを繰り返して後, 熱膨脹测定器 によつて声照鉛化狀態を調べた。其結果は Fig. 4 に示してある。てれから各試料の 㫮鉛化開始溫度を求むると圖中 $\mathrm{B}^{\circ} \mathrm{C}$ 及 Table 5 に示寸如くなる。台燒鈍せる街料 の組織を觀るに勿諭ての場合でる何れる Photo.3 及 4 に類似の縕織となつて居るが、 燒大れ间数の多いもの程パーライトの量が 少くなつて居る。

以上翼驗の結果に上ると燒入れ繰り返し

Table 5.

\begin{tabular}{|c|c|c|c|}
\hline $\begin{array}{l}\text { Specimen } \\
\text { No. }\end{array}$ & $\begin{array}{c}\text { No. of repetition } \\
\text { of } \\
\text { quenching }\end{array}$ & $\begin{array}{c}\text { Beginning temp. } \\
\text { of } \\
\text { graphitization }\end{array}$ & Remarks \\
\hline $\begin{array}{cc}\text { A. b. } & 1 \\
\text { " b } & 2 \\
" & 3 \\
" & 4\end{array}$ & $\begin{array}{l}1 \\
2 \\
4 \\
6\end{array}$ & $\begin{array}{l}889 \\
870 \\
860 \\
857\end{array}$ & $\begin{array}{l}\text { 常に } 810^{\circ} \mathrm{C} よ \\
\text { y } 15^{\circ} \mathrm{C} \text { の水中 } \\
\text { に燒入れす }\end{array}$ \\
\hline
\end{tabular}




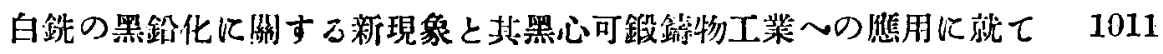

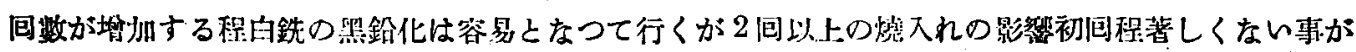
認められる。

\section{第三節 白鉄を一定溫度にて加勢せる場合に現はるる新現豕の研究

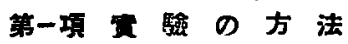

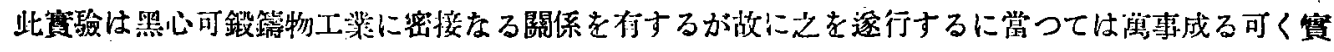

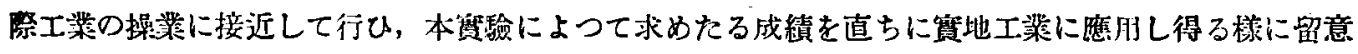
したのである。

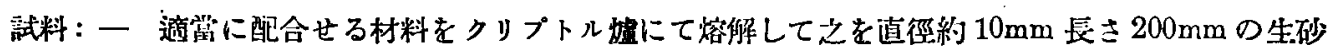

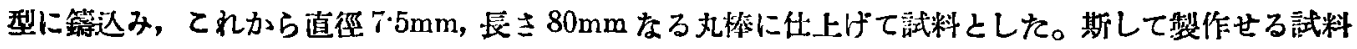

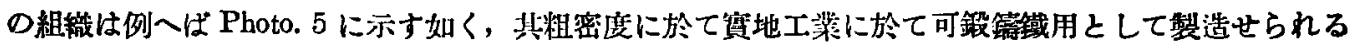
白铣籍物の組織と大差がないのである。

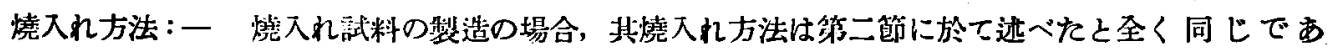
る。

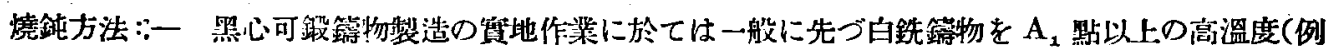
へば $900^{\circ} \mathrm{C}$ 或は $870^{\circ} \mathrm{C}$ )に長特間保持して遊離セメンタイトを全く熙鉛化せしめて後，極めて徐々に

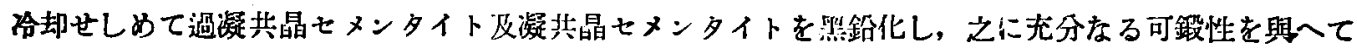
居る。從つて此研究に於ても文萢料を先づ $\mathrm{A}_{2}$ 點以上の所要の溫度迄加熱し，同溫度を保持して遊耀 セメンタイトを完全に熙鉛化せしめたる後，嘘中椧却を行ふかか，又必要に應しては一定冷却速度を以 て $\operatorname{Ar}_{1}$ 點以下の溫度迄冷却して凝共晶セメンタイトを析出せしめたる後， $\mathbf{A}_{1}$ 點以下に於ける所要の 溫度に保ちて過凝共晶セメンタイト（若し传在して居るとすれば）及凝共晶セメンタイトの熙鉛化狀 態を追究する事とした。今便宜上菊田博士の例に從ひ，此賔獫に於て $A_{2}$ 點以上の溫度に保持した場

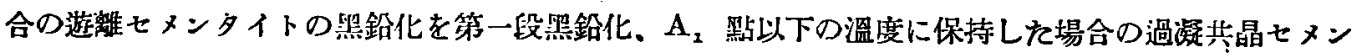
タイト及凝共晶セメンタイトの熙鉛化を第二段㫮鈖化と名付ける事とする。

今試料の加熱及冷却速度を示すと次の如くである。

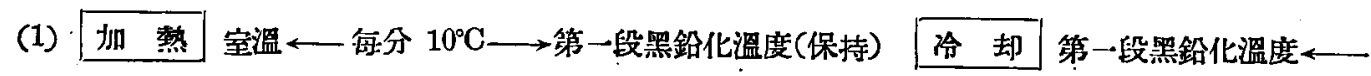
爈中椧却—室溫

或梳

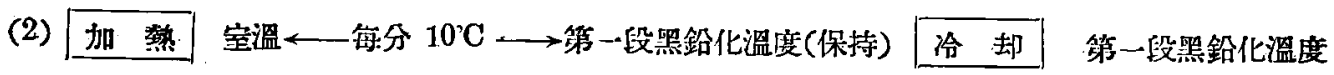
$\longleftarrow$ 每分 $10^{\circ} \mathrm{C} \longrightarrow 700^{\circ} \mathrm{C} \longleftarrow$ 每分 $10^{\circ} \mathrm{C} \longrightarrow 730^{\circ} \mathrm{C}$ 或仙 $740^{\circ} \mathrm{C}$ (保持)—嘘中冷却 —室溫 


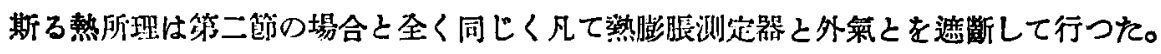

第一段黑鉛化溫度及第二段照鉛化溫度に於て長時间一定溫度を保持する事は甚だ困難と考一られた

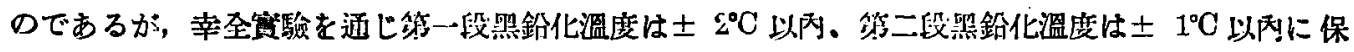
持する事が出來た。而してこの實驗に於ては別に自記高溫計を以て一タ熱所理の有㥞を記錄せしめた のである。又熱所理の閒に於ける目盛の讀みは加熱及冷却中は $10^{\circ} \mathrm{C}$ 或は $20^{\circ} \mathrm{C}$ 每に取り，一定溫度 に保持せる中は 10 分間每に取つた。熱所理を終りたる試料ばーく顯微唋試驗を行つた事は勿論です る。

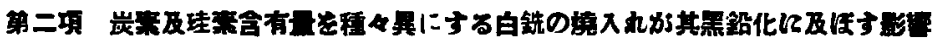

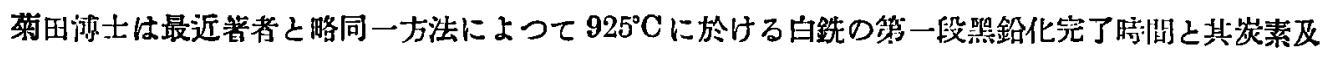
珪素合有量との關係を求め, 又或梨の白銑に就ては $710^{\circ} \mathrm{C}$ に於ける算二段黑鉛化完了時間之の關係

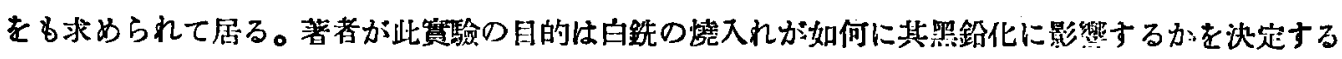

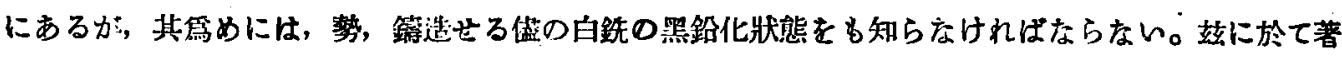
者は菊田淤士の質驗を再び繰り返す事となつた。但しての賽驗に於ては芶田博士の如く第一段㫮鉊化

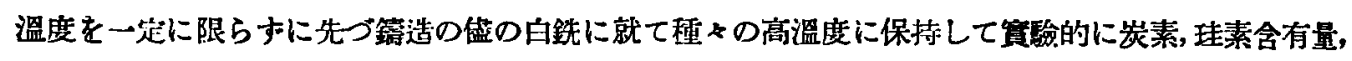

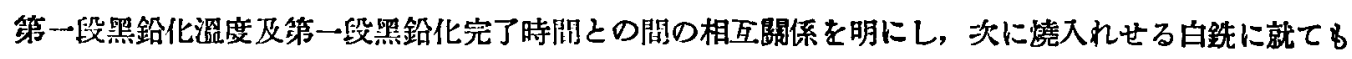

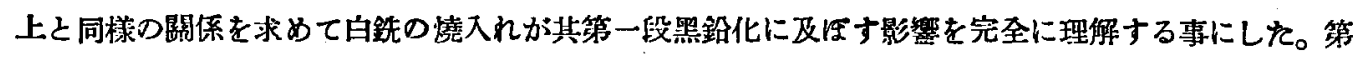

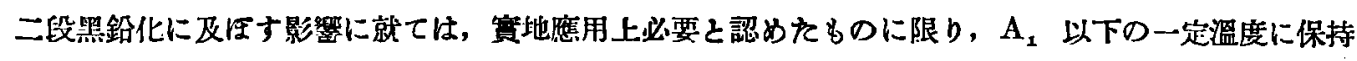

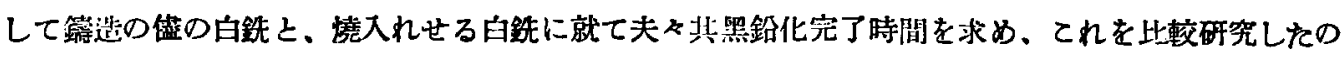
である。以下筫驗の詳細に就て述べる。

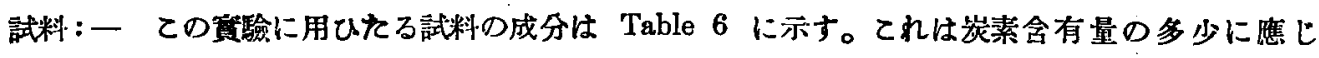
て La〜日なる 5 つの耕に分つてある。ての表中 L.C.4 は珪素量多きに過を其破面に照色斑點を示

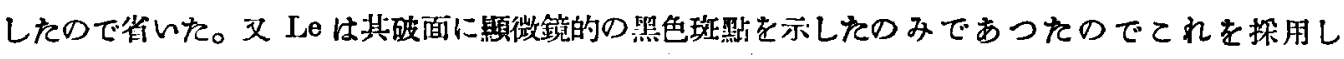
to

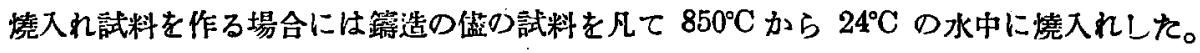

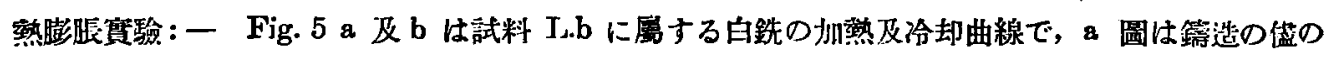
圾料，b圖は憢入れ試料に就て實驗せる結果である。圆に於て横軸は溫度を表はし，縱䛣は試料の延

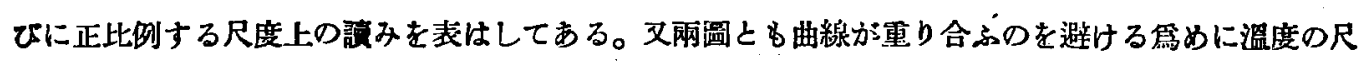

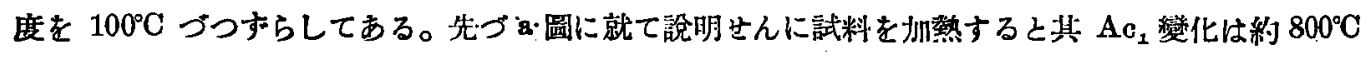
に表はれる。更に溫度を上げ所要の溫度に保持すると遊雗セメンタイトの分解が始つて曲線は横軸に

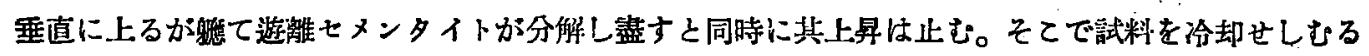


白銧の黑鉛化に關す万新現象之其黑心可鍛鏝物工業への應用に就て

\section{Table 6.}

\begin{tabular}{|c|c|c|c|c|c|c|c|c|c|c|c|c|c|c|}
\hline \multirow{2}{*}{\multicolumn{2}{|c|}{$\begin{array}{c}\text { Specimen } \\
\text { No. }\end{array}$}} & \multicolumn{4}{|c|}{ Composition } & \multicolumn{2}{|l|}{$\%$} & \multirow{3}{*}{\begin{tabular}{|l|}
$\begin{array}{l}\text { Condition } \\
\text { of } \\
\text { Specimen } \\
\text { As Cast }\end{array}$ \\
\end{tabular}} & \multirow{3}{*}{$\begin{array}{l}\text { Heat } \\
\text { Treatment } \\
\text { ro. } \\
A-1 \\
A-2\end{array}$} & \multirow{3}{*}{$\begin{array}{c}\text { Graphlija- } \\
\text { tion Curve } \\
\text { No. } \\
5-1 \\
S-2\end{array}$} & \multirow{2}{*}{\multicolumn{2}{|c|}{ 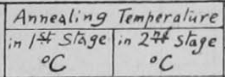 }} & \multicolumn{2}{|c|}{$\begin{array}{l}\text { Annealing Time for } \\
\text { complete Graphitigation }\end{array}$} \\
\hline & & $c$ & Si & $M_{n}$ & $P$ & $S$ & $C_{u}$ & & & & & & $\mathrm{im} / \sqrt{4} 5 \sqrt{495}$ & in $2^{\text {ndstage }}$ \\
\hline & \multirow[b]{2}{*}{1} & \multirow{2}{*}{1.97} & \multirow[b]{2}{*}{0.64} & \multirow[b]{2}{*}{0.35} & \multirow[b]{2}{*}{0.088} & \multirow[b]{2}{*}{0.051} & \multirow[b]{2}{*}{0.21} & & & & $\begin{array}{r}1.010 \\
980\end{array}$ & & $\begin{array}{l}3^{n} \cdot 20^{m i n} \\
820\end{array}$ & \\
\hline & & & & & & & & Quenched & $\begin{array}{l}Q-1 \\
Q-2\end{array}$ & $\begin{array}{l}Q-1 \\
Q-2\end{array}$ & $\begin{array}{l}970 \\
930 \\
\end{array}$ & & $\begin{array}{cc}2 & 30 \\
5 & 0\end{array}$ & \\
\hline & \multirow[b]{2}{*}{2} & \multirow[b]{2}{*}{2.02} & \multirow[b]{2}{*}{1.41} & \multirow[b]{2}{*}{0.39} & \multirow[b]{2}{*}{0.123} & \multirow[b]{2}{*}{0.059} & \multirow[b]{2}{*}{0.17} & As Cast & $\begin{array}{l}A-1 \\
A-2\end{array}$ & $\begin{array}{l}s-3 \\
s-4\end{array}$ & $\begin{array}{l}960 \\
9.10\end{array}$ & & $\begin{array}{cc}2 & 0 \\
5 & 30\end{array}$ & \\
\hline & & & & & & & & Quenched & $\begin{array}{l}Q-1 \\
Q-2\end{array}$ & $\begin{array}{l}Q-3 \\
Q-4\end{array}$ & 950 & & $\begin{array}{ll}0 & 40 \\
1 & 50\end{array}$ & \\
\hline & \multirow{2}{*}{3} & \multirow{2}{*}{2.05} & \multirow[b]{2}{*}{1.70} & \multirow[b]{2}{*}{0.35} & & & & As Cast & $\begin{array}{l}A-1 \\
A-2\end{array}$ & $\begin{array}{l}S-5 \\
s-6\end{array}$ & $\begin{array}{l}970 \\
920\end{array}$ & & $\begin{array}{ll}1 & 0 \\
3 & 0\end{array}$ & \\
\hline & & & & & 0.102 & 0.057 & 0.22 & Quenched & $\begin{array}{l}Q-1 \\
Q-2\end{array}$ & $\begin{array}{l}Q-5 \\
2-6\end{array}$ & $\begin{array}{l}970 \\
920\end{array}$ & & $\begin{array}{r}0 \\
1 \quad 0 \\
\end{array}$ & \\
\hline & & & & & & & & As Cast & $\begin{array}{l}A=1 \\
A=2\end{array}$ & $\begin{array}{l}s-7 \\
s-8\end{array}$ & $\begin{array}{l}970 \\
920\end{array}$ & & $\begin{array}{rr}0 & 50 \\
2 & 0\end{array}$ & hr. min. \\
\hline & 4 & 1.93 & 1.96 & 0.30 & 0.101 & 0.052 & 0.22 & Quenched & $\begin{array}{l}Q-1 \\
Q-2\end{array}$ & {$\left[\begin{array}{cc}Q-7 & Q-7 \\
2-8\end{array}\right.$} & $\begin{array}{l}970 \\
920\end{array}$ & 740 & $\begin{array}{ll}0 & 0 \\
0 & 30\end{array}$ & 230 \\
\hline & & & & & & & & As Cast & $\begin{array}{l}A-1 \\
A-2\end{array}$ & $\begin{array}{l}s-9 \\
s-10\end{array}$ & $\begin{array}{r}1.010 \\
970\end{array}$ & & $\begin{array}{rr}4 & 30 \\
9 & 0 \\
\end{array}$ & \\
\hline & I & 2.46 & 0.67 & 0.32 & 0.099 & 0.057 & 0.23 & Quenched & $\begin{array}{l}Q-1 \\
Q-2 \\
Q-3\end{array}$ & $\begin{array}{l}Q-9 \\
Q-10 \\
Q-11\end{array}$ & $\begin{array}{r}1.010 \\
970 \\
920\end{array}$ & & $\begin{array}{ll}1 & 20 \\
2 & 30 \\
5 & 30\end{array}$ & \\
\hline & 2 & 2.43 & & & & & 0.23 & As Cast & $\begin{array}{l}A-1 \\
A-2 \\
A=3 \\
A-4\end{array}$ & $\mid \begin{array}{c}s-11 \\
s-12 \\
s-13 \\
s-13 \\
s-14\end{array}$ & $\begin{array}{l}970 \\
950 \\
920 \\
880\end{array}$ & 730 & $\begin{array}{cc}5 & 0 \\
7 & 0 \\
13 & 0 \\
400 & 0 \\
\end{array}$ & $23+x$ \\
\hline & 2 & 2.43 & 0.14 & 0.34 & 0.102 & 0.057 & 0.23 & Quenched & $\begin{array}{l}Q-1 \\
Q-2 \\
Q-3 \\
Q-4\end{array}$ & $\begin{array}{c}Q-12 \\
Q-13 \\
Q-14 . Q-14 \\
Q-15\end{array}$ & $\begin{array}{l}970 \\
940 \\
920 \\
880\end{array}$ & 730 & $\begin{array}{|cc|}1 & 20 \\
2 & 30 \\
3 & 30 \\
7 & 0 \\
\end{array}$ & $20+x$ \\
\hline$L-b$ & 3 & 2.38 & & & & & 0.23 & As Cast & $\begin{array}{l}A-1 \\
A-2 \\
A=3 \\
A-4\end{array}$ & $\begin{array}{c}s-15 . s^{\prime}-15 \\
s-16 \\
s-17 \\
s-18 . s-18^{\prime}\end{array}$ & $\begin{array}{l}970 \\
950 \\
930 \\
890 \\
\end{array}$ & $\begin{array}{l}730 \\
730\end{array}$ & $\begin{array}{cc}2 & 10 \\
3 & 20 \\
5 & 0 \\
9 & 30\end{array}$ & $\begin{array}{ll}21 & 0 \\
22 & 0\end{array}$ \\
\hline & 3 & 2.38 & 1.25 & 0.37 & 0.095 & 0.058 & 0.23 & Quenched & $\begin{array}{l}Q-1 \\
Q-2 \\
Q-3 \\
Q-4\end{array}$ & $\begin{array}{l}Q-16 \cdot Q^{\prime}-16^{\prime} \\
Q-17 . Q^{\prime}-17^{\prime} \\
Q-18 . Q^{\prime}-18^{\prime} \\
Q-19 . Q^{\prime}-19^{\prime}\end{array}$ & $\begin{array}{l}970 \\
930 \\
890 \\
860\end{array}$ & $\begin{array}{l}730 \\
730 \\
730 \\
730 \\
\end{array}$ & $\begin{array}{cc}0 & 40 \\
1 & 0 \\
2 & 0 \\
4 & 0 \\
\end{array}$ & $\begin{array}{rr}5 & 0 \\
4 & 0 \\
5 & 30 \\
8 & 0\end{array}$ \\
\hline & 1 & 2.37 & & & & & 1023 & As Cast & $\begin{array}{l}A-1 \\
A=2 \\
A-3\end{array}$ & $\mid \begin{array}{c}S-19 . S^{\prime}-19^{\circ} \\
S-20 \\
S-21 . S^{\prime}-21^{\prime}\end{array}$ & $\begin{array}{l}970 \\
930 \\
830\end{array}$ & $\begin{array}{l}740 \\
740\end{array}$ & $\begin{array}{lr}1 & 30 \\
3 & 0 \\
6 & 0\end{array}$ & 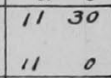 \\
\hline & 4 & 2.37 & 1.54 & 0,37 & 0.102 & 0.057 & 0.23 & Quenched & $\begin{array}{l}Q-1 \\
Q-2 \\
Q-3\end{array}$ & $\begin{array}{l}Q-20, Q^{\prime}-20^{\prime} \\
Q-21, Q^{\prime}-21^{\prime} \\
Q-22, Q^{\prime}-22^{\prime}\end{array}$ & $\begin{array}{l}970 \\
910 \\
860 \\
\end{array}$ & $\begin{array}{l}740 \\
740 \\
740 \\
\end{array}$ & $\begin{array}{l}030 \\
110 \\
230 \\
\end{array}$ & $\begin{array}{ll}4 & 0 \\
3 & 0 \\
3 & 0\end{array}$ \\
\hline & 1 & 2.71 & 0.65 & 0.24 & 0.102 & 0.060 & 024 & As Cast & $\begin{array}{l}A-1 \\
A-2\end{array}$ & $\begin{array}{l}S-22 \\
S-23\end{array}$ & $\begin{array}{r}1.010 \\
970 \\
\end{array}$ & & $5_{8+x}^{510}$ & \\
\hline & 1 & 2.81 & 0.63 & 0,24 & 0.102 & 0,060 & 0.24 & Ouenched & $\begin{array}{l}Q-1 \\
Q-2\end{array}$ & $\begin{array}{l}Q-23 \\
Q-24\end{array}$ & $\begin{array}{l}970 \\
920\end{array}$ & & $\begin{array}{rr}2 & 30 \\
7 & 0\end{array}$ & \\
\hline & 2 & 2.80 & 0.94 & 0.21 & 0.109 & 0.058 & 0.23 & As Cast & $\begin{array}{l}A-1 \\
A-2 \\
A-3\end{array}$ & $\begin{array}{l}S-24 \\
S-25 \\
S-26\end{array}$ & $\begin{array}{l}970 \\
930 \\
910 \\
\end{array}$ & & 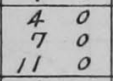 & \\
\hline$L-c$ & & 2.80 & & 0.21 & 0.107 & 0.058 & 0.23 & Quenched & $\begin{array}{l}Q-1 \\
Q-2 \\
Q-3\end{array}$ & $\begin{array}{l}Q-25 \\
Q-26 \\
Q-27\end{array}$ & $\begin{array}{l}970 \\
930 \\
890\end{array}$ & & $\begin{array}{rr}1 & 0 \\
2 & 30 \\
6 & 0\end{array}$ & \\
\hline & & & 135 & 0.28 & & & 0.11 & As Cast & $\begin{array}{l}A-1 \\
A-2 \\
A-3\end{array}$ & $\begin{array}{c}S-27 . S-27 \\
S-28 \\
S-29\end{array}$ & $\begin{array}{l}950 \\
920 \\
890\end{array}$ & 740 & $\begin{array}{rr}3 & 6 \\
5 & 0 \\
10 & 0 \\
\end{array}$ & 11 \\
\hline & 3 & 2.79 & 1.35 & 0.28 & 0.179 & 0.072 & 0.11 & Auenched & $\begin{array}{l}Q-1 \\
Q-2 \\
Q-3\end{array}$ & $\mid \begin{array}{c}Q-28 \\
a-29 . Q^{\prime}-29^{\prime} \\
Q-30\end{array}$ & $\begin{array}{l}940 \\
900 \\
860\end{array}$ & 740 & $\begin{array}{ll}0 & 30 \\
1 & 20 \\
3 & 30 \\
\end{array}$ & 13 \\
\hline & 4 & 2.81 & 1.58 & 0.23 & 0.109 & 0.057 & 0.24 & & & M,rtlec & $d$ & & & \\
\hline & & & & & & 0,049 & 0,18 & As Cast & $\begin{array}{l}A-1 \\
A-2\end{array}$ & \begin{tabular}{|l|}
$S-30$ \\
$S-31$ \\
\end{tabular} & $\begin{array}{l}970 \\
920 \\
\end{array}$ & & $\begin{array}{cc}4 & 30 \\
9 & 0 \\
\end{array}$ & \\
\hline & $\gamma$ & 3.33 & 1.03 & 0.15 & 0.088 & 0,044 & 0.18 & Quenched & $\begin{array}{l}Q-1 \\
Q-2\end{array}$ & $\begin{array}{c}Q-3 I \\
Q-32 \cdot Q^{\prime}-3 z^{\prime}\end{array}$ & $\begin{array}{l}970 \\
920 \\
\end{array}$ & 740 & $\begin{array}{ll}1 & 30 \\
2 & 30 \\
\end{array}$ & 5 \\
\hline$L-\stackrel{+}{e}$ & 1 & 377 & 0.43 & 0.05 & 0.010 & 0.016 & 0.06 & As Cast & $A-1$ & $S-32$ & 970 & & 100 & \\
\hline & & & & & & & & Quenched & $Q-1$ & $2-33$ & 970 & & 530 & \\
\hline
\end{tabular}

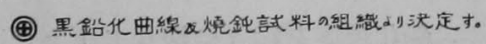

米破面に微量喅巴珽点片 


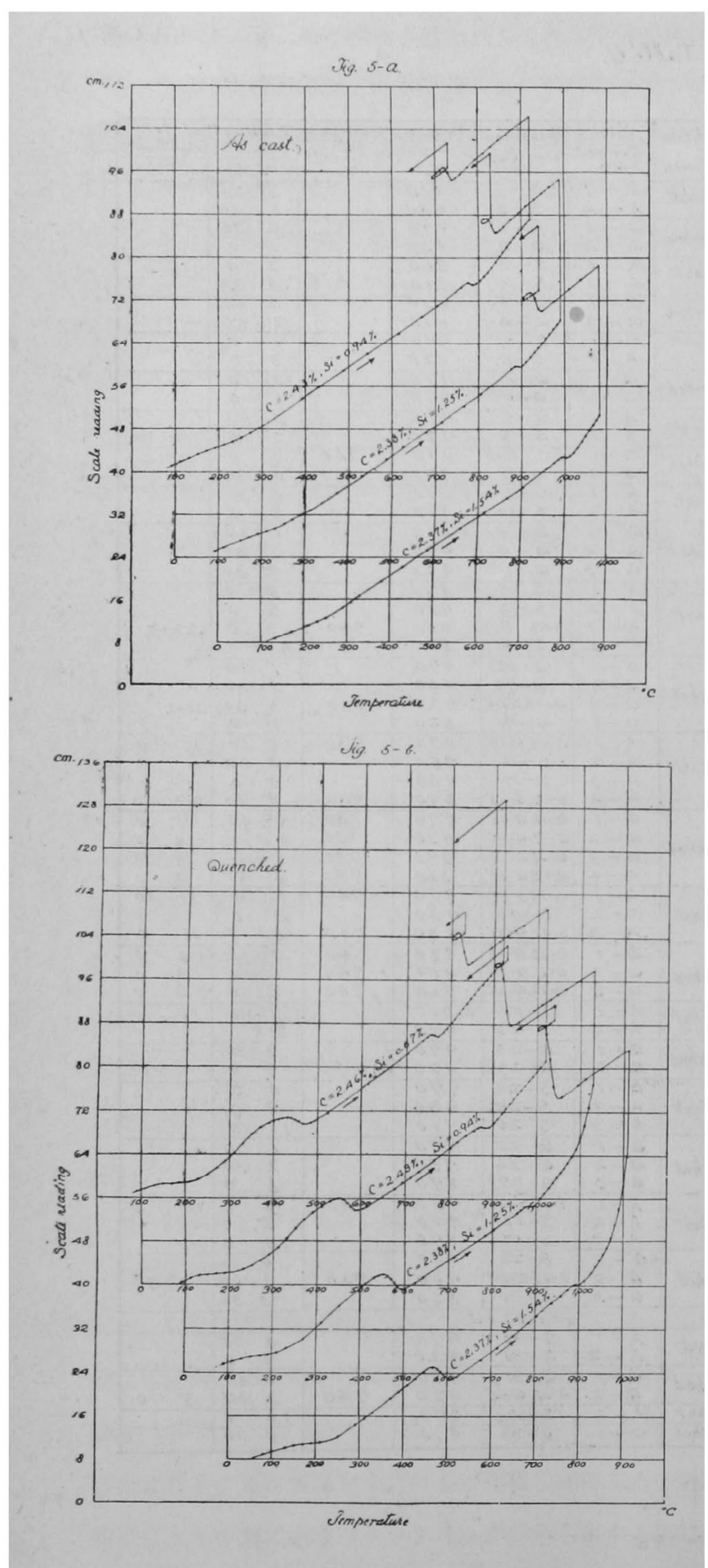

と約 $750^{\circ} \mathrm{C}$ から $\mathrm{Ar}_{1}$ 継化が始まる。 $\mathrm{Ar}_{1}$ 槡化が終つて挠、再び溫度を少し く上昇せしめ、 $A_{2}$ 點の下の一定溫度 $\left(730^{\circ} \mathrm{C}\right.$ 或は $\left.740^{\circ} \mathrm{C}\right) に て$ 再び溫度を保 持すると、曲線は再び横斬に垂直に上 昇し始める。てれはパーライト、七メ ンタイト及浤し存在するとせ代過凝共 昆セメンタイトが品鉛化する爲めであ る。次に此等のセメンタイトの消失即 ち曲線の上景が止みて後侙料は㠊中冷 却する。

燒入れ藏料の少熱に際しては・前節 に說明せる如く約 $200^{\circ} \mathrm{C}$ 㕅 $5000^{\circ} \mathrm{C}$ に於 て二段の收縮が表はれる。Ac 造の㒒の試料之同一溫庭に表はれる。 纷溫度を上げると珪素量の多い試料は $830^{\circ} \mathrm{C}$ 位から遊離セメンタイトの㫮鉛 化が始まり曲線は急速に上昇し始め ろ。而して所要の第一段品鉛化溫度に 犊する迄に已に遊離七メンタイトの大 牛は分解して居て、同溫度に達して媵 殘部の遊離セメンタイトの分解によつ て曲線は橫軸に垂直に上昇する。其後 は前の場合と變りがない。

䇸造の呰の試料でも燒入れ試料でる 第一段熙鉛化のみを目的としたものは 凡て $\mathbf{b}$ 圖の最上曲線に示寸如くに第一 段照鉿化が完了して後教中冾却を行つ to

Table:6 に示す弪料は凡て第一段熙 鉛化溫度を楮々に探りて Fig 5 に示す と全く同栐の熱所理を施して夫ね第一 


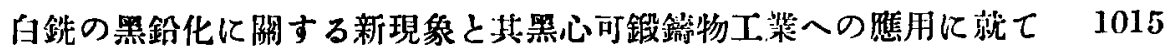

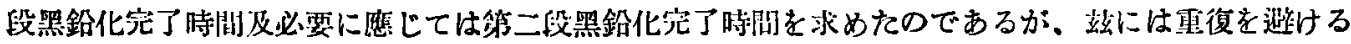
雪め單に代表的の例とし Fig. 5 を揭代他の陚料の州熱及冷却曲線は總て省略する事にした。但し第 一段及第二段㫮鉛化期に於ける各試料の熙鉛化進行の狀態は此望驗に於て極めて重要なる點であるの

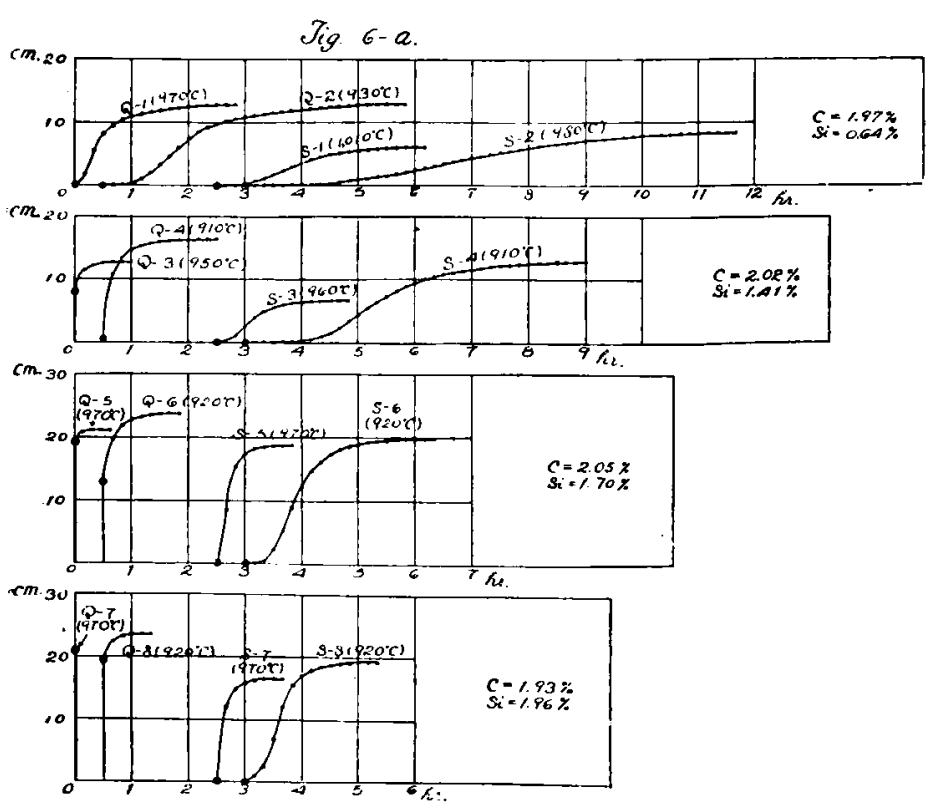

でてれを詳縕に圖实する事 にした。Fig. 6 a〜e 及 Fig. $7 \mathrm{a}$ 及 b がそれであ る。兩圆に劫て横䡃は所要 の黑鉛化溫度に保持せる時 間を表はして、縱斬は稢料 の延びを表はす。てれは黑 鉛化せるセメンタイトの量 に相當するものである。 圆中 $S \cdot$ 及 $S^{\prime}$ 曲線は䥄造 の盐の試料、Q 及 $\mathrm{Q}^{\prime}$ 曲線 は燒入れ試料の黑鉛化曲線 を示す。又 Fig. 6 に於て a 圆怡麦素 $2.0 \%$ の白銑.
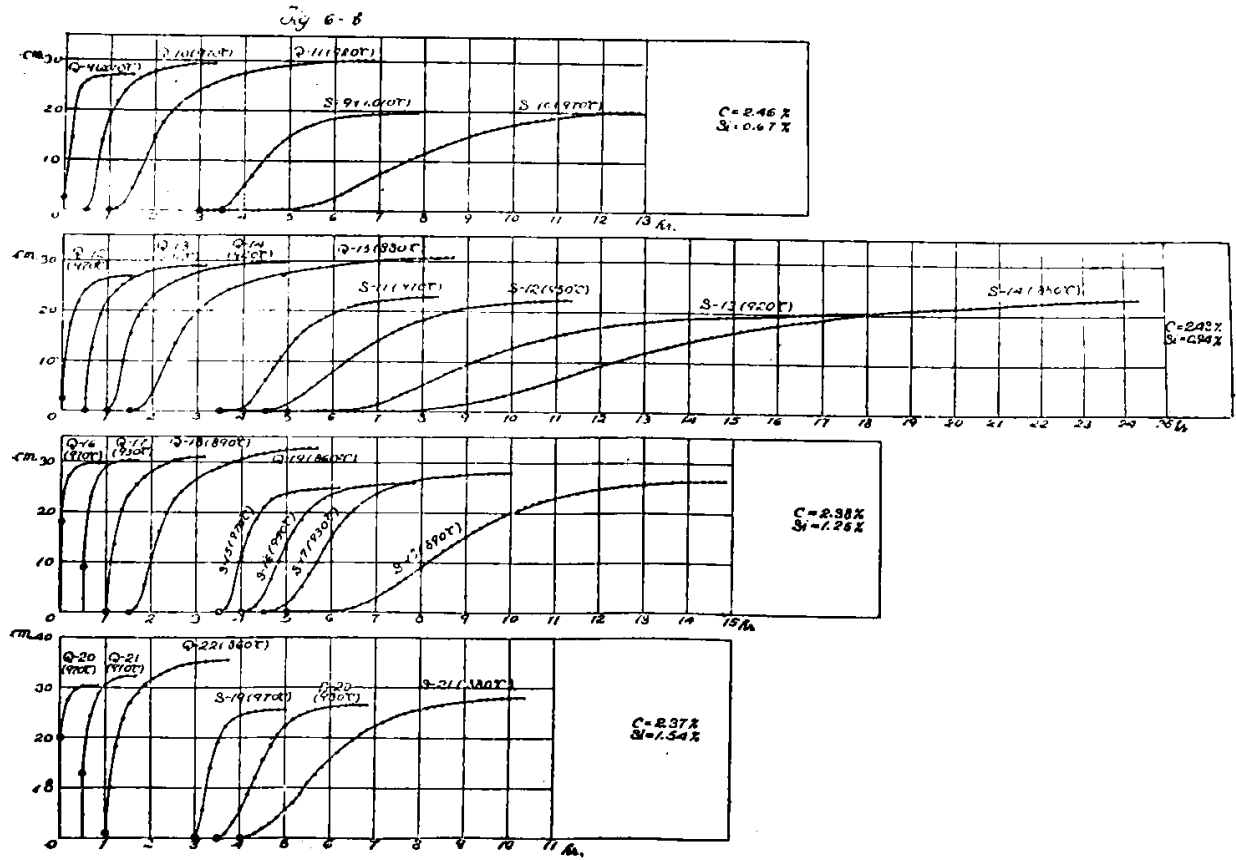
Jig. 6-c
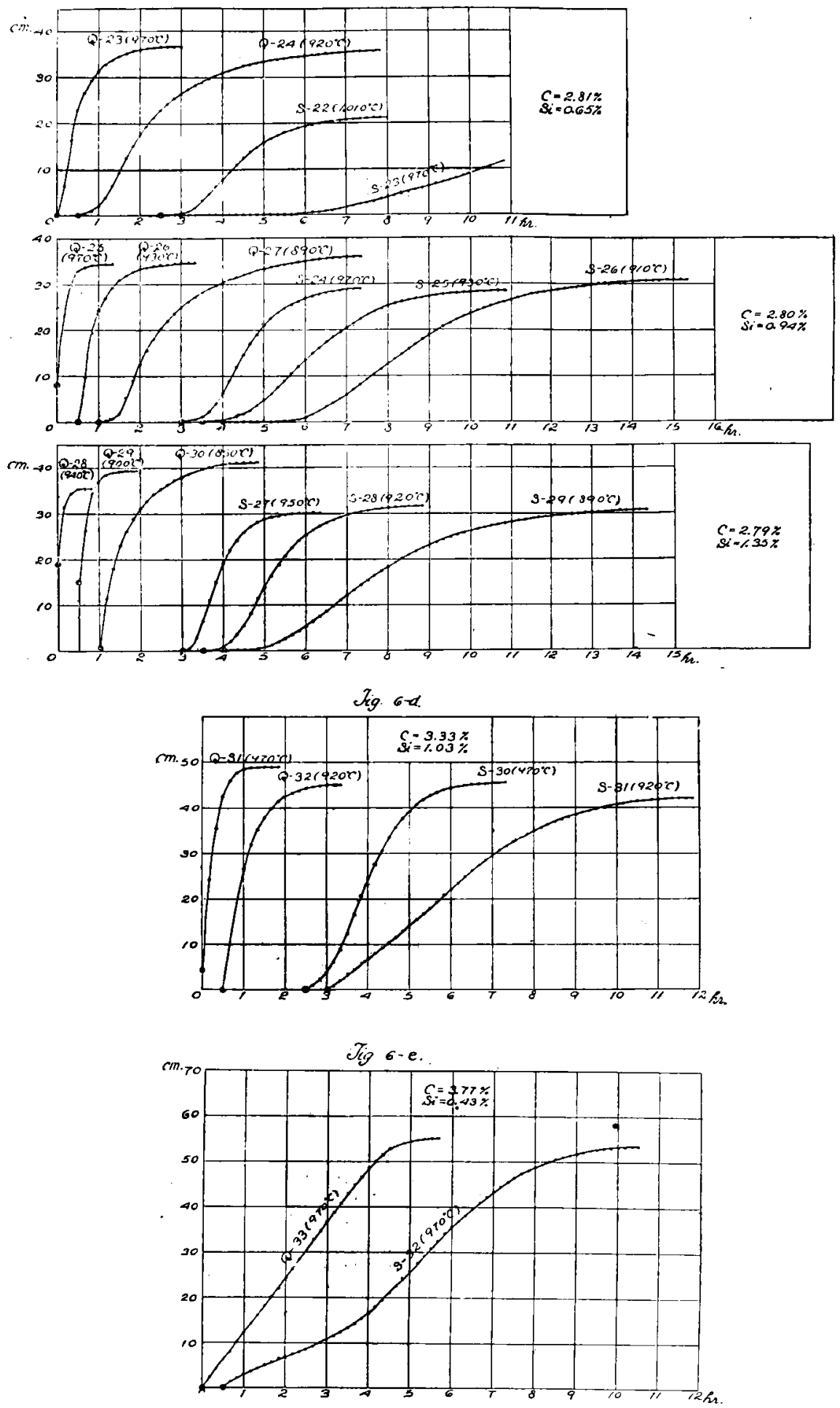


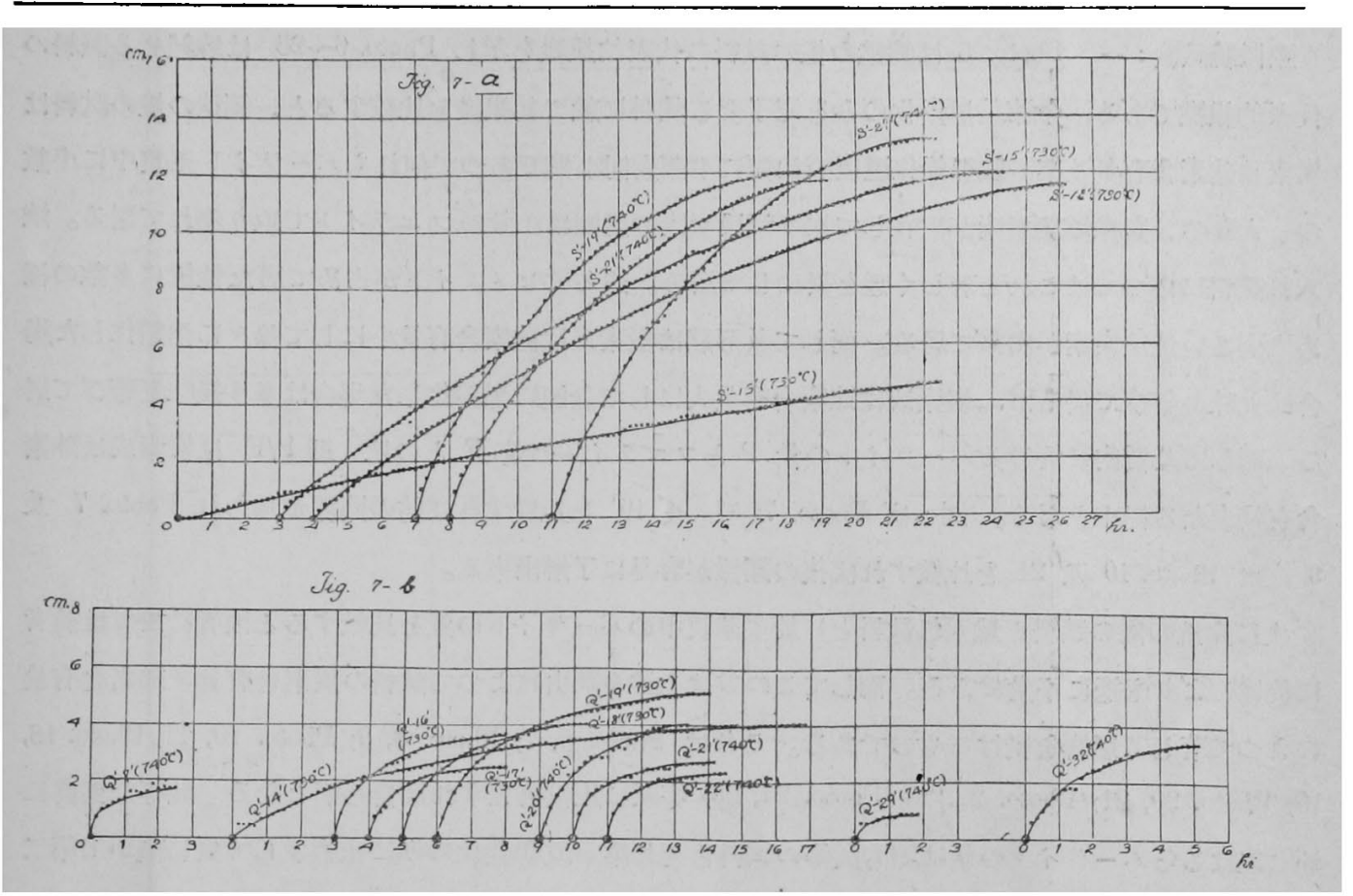

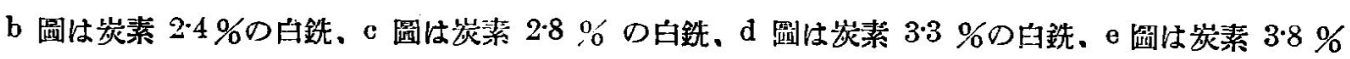

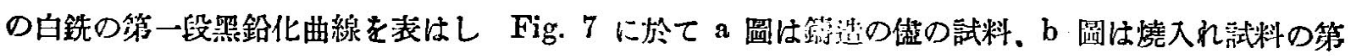

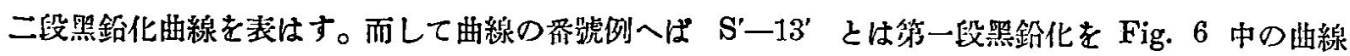
S-13に從つて完了せしめたる郦料の第二段熙鉿化曲線を示するのである。台此等の曲線中 Q-20 の如きに於ては零時間に於て $200 \mathrm{~mm}$ の延びを示して居るのは Fig. 5 b から知らる」如く試料の溫

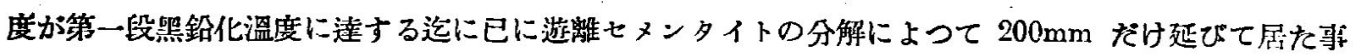
を示して居る。他の此稓の曲線も又てれと同㥞の事を表はす。

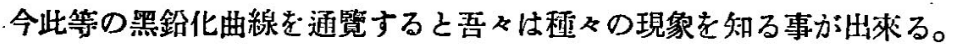

先づ第一に第一段黑鉛化完了時墹に於ても又第二段熙鉛化完了時䦚に於ても燒入れ試料が他に比し て迷に短い事が知られる。てれに就ては後に詳しく論する事とする。

次に試料の㞸素含有量が多い程第一段㷛鉿化曲線の产」さが大である事である。てれは炭素含有量が 大なる程試驗の遊離セメンタイトの量が㙫加する事寶による事は云ふ迄もない。

又同量の含炭量であつても珪素含有量が大なる程第一段埋鉿化曲線の高さが大なるは珪素含有量が 大はる程遊離セメンタイトの量が䐣加する事筫によるものである。

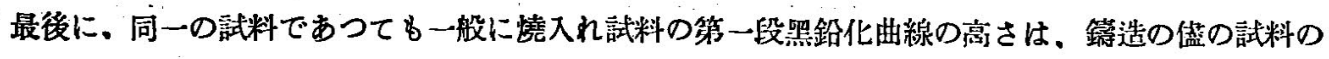
それに比して遙に大で、逆に前者の第二段黑鉛化曲線の高さが後者のそれに比して遥に小なるは起だ 興味ある現象である。此現象は全く鉛黑化に與つたセメンタイトの量に基因する事は次に述べる。 


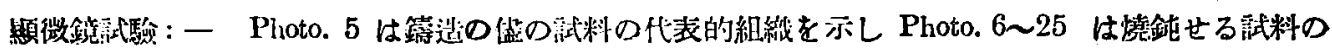

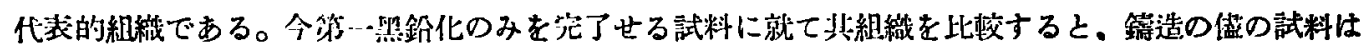

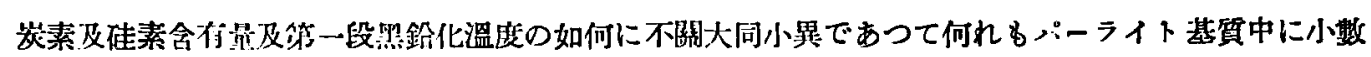

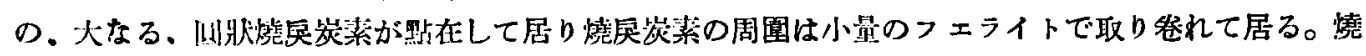

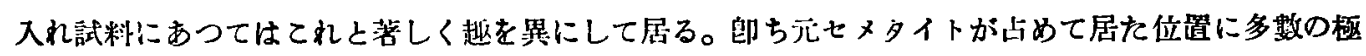

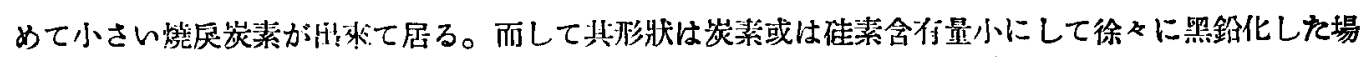

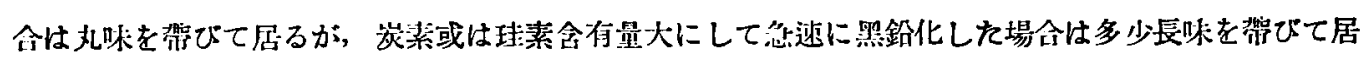
る。而して基質內に於けるパーライトの量 $\mathrm{P}$ とフェライトの量 $\mathrm{F}$ との比 即 $\mathrm{P} / \mathrm{F}$ は炭素或は珪素 含有显大なる程小となる。例人ば Photo. テ・11 及. 19 を比较すれば前の關係が知られ Photo. 7 及 9 或はPloto. 19 \& 21 を此較すれ後の關係が容易に了解H來る。

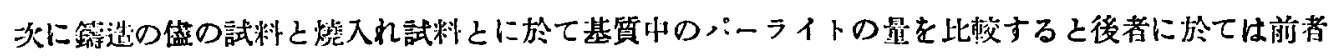
に於けるよりも遙に小量である。而してての差は上述の理山によつて試料の炭素含有量及珪素含有量 によつて著しく影響を受けるものである。てれは Photo. 6, 7; Photo. 8, 9; Photo. 10, 11; Photo. 18, 19; Plıto. 20, 21; Photo. 22, 23; Photo. 24, 25; 等页に比较㑡究すれば自ら明となる。此等の寫真に 於て現はるるパーライトの量は即ち此等の倵料老若し第一段㫮鉛化のみに止めすして更に續いて第二 段㫮鉛化をも完了せしもれば第二段照鉛化曲線に其高さとなりて表はんて来るものである。茲に於て

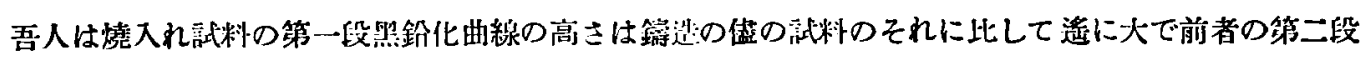
黑鉛化明線の高さはてれと反跬に後者のそれに比して迷に小なる理由を明瞭に理解する事が出來たの

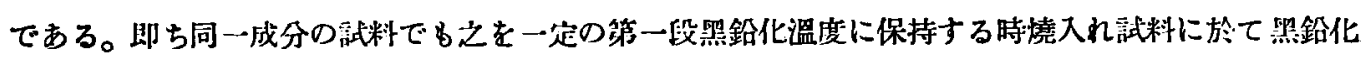

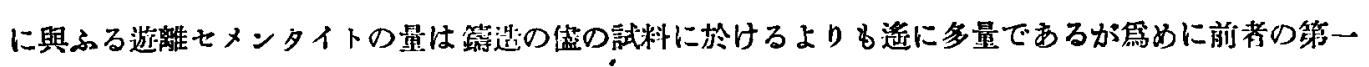
段黑鉛化曲線の高さは後者のそれに比して遥に大となるが前者に於て第二段㫮鉛化に鴡るセメンタイ トの量は逆に後者のそれに比して选に小となり從つて前者の第二段熙鉛化曲線の高さは後者のそれに 比して遙に小となるものである。

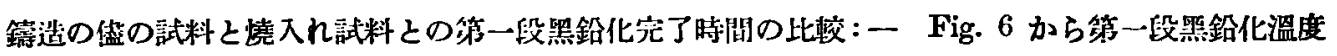

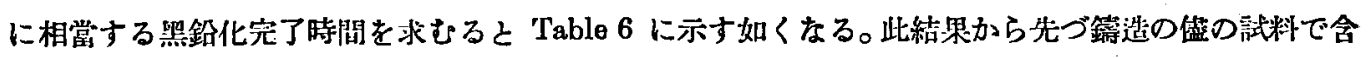
若量夫ぬ $2.0 \%, 2.4 \%, 2.8 \%$ 及3.3\%の白銑に就て第一段照鉛化溫度と同完了時間との關係を圖示す ると Fig. $8 \mathrm{a}$ d となる。此關係から各白鉎系に就て珪素量と第一段哇鉊化完了時間との關係を圆示 すれば Fig. 9 a〜c となり.更に又 Fig. 9 によつて珪素含有量夫を 0.8 \%, 1.\%及 1.3\%の白鉄に 於ける桨絜含有量と第一段照鉛化完了時閉との關係を圖示すると Fig. 10 a〜 とをる。

上と同㥞の順序でてれ等の關係を燒入れ試料に就て求めると Fig. 11 a〜d, Fig. 12. a〜c. 及 Fig. 13 a〜d となる。

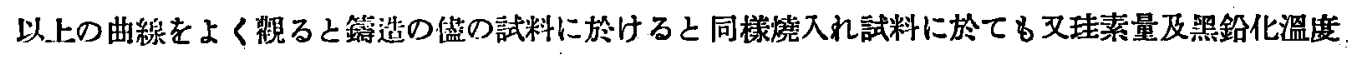



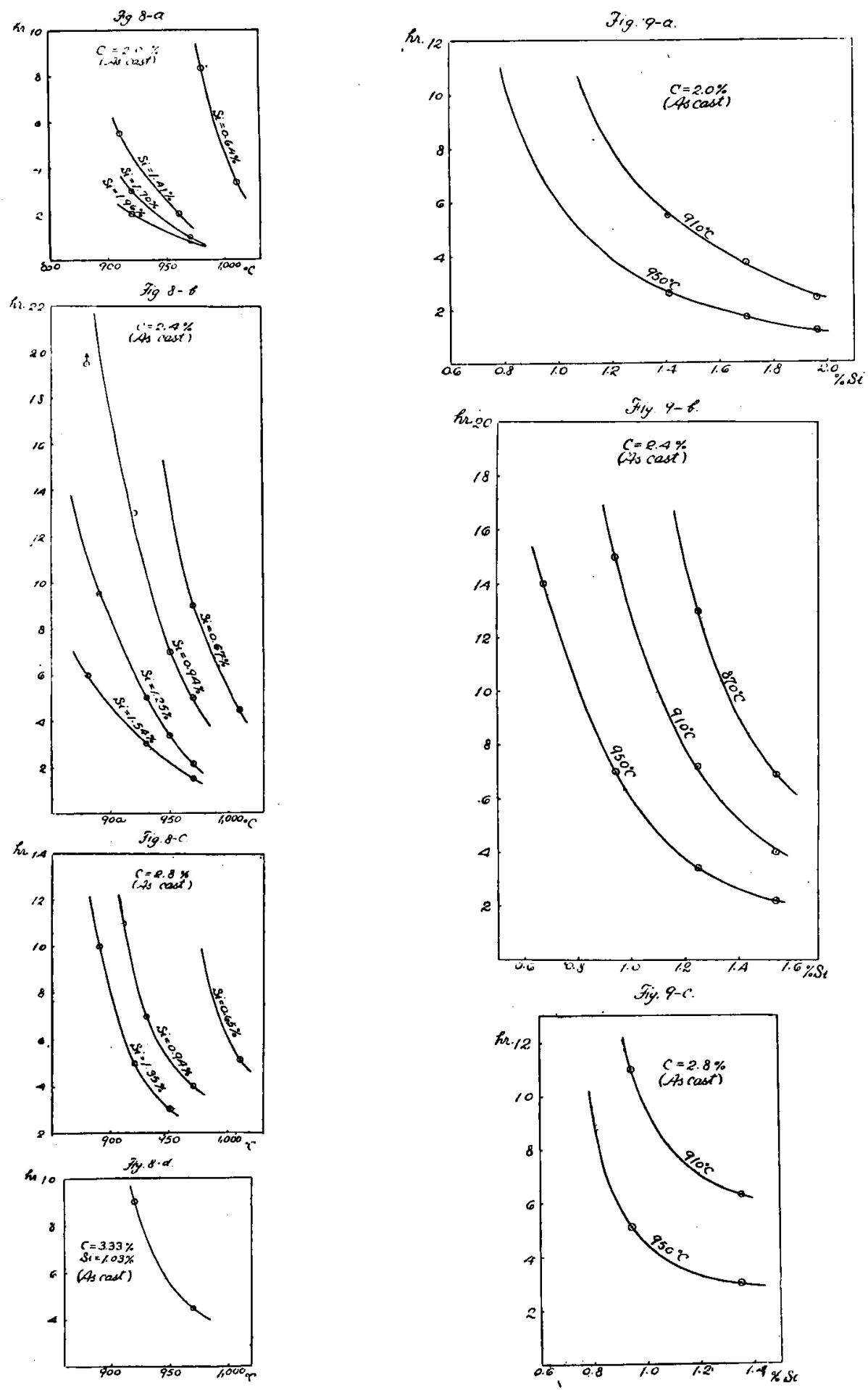

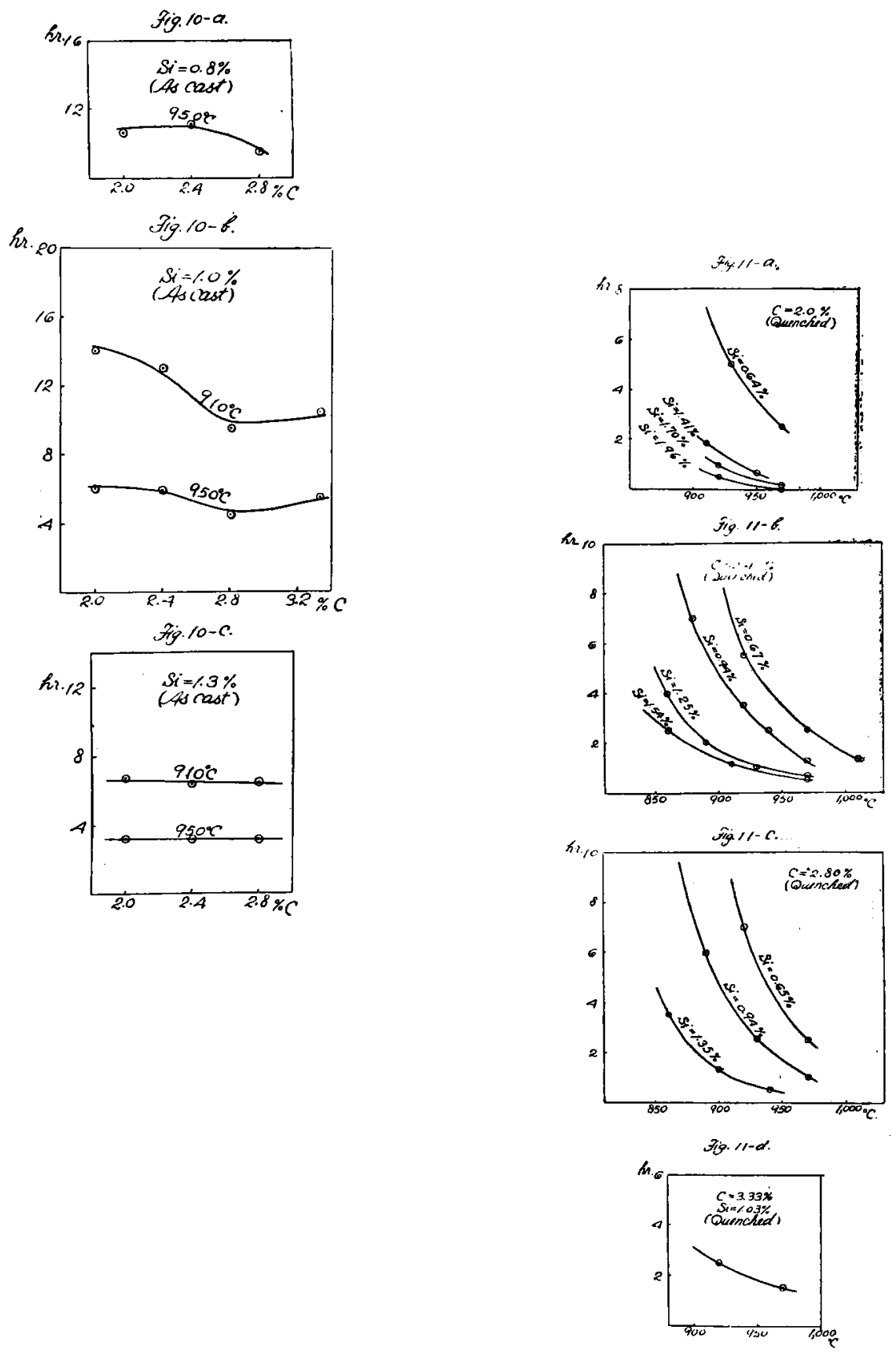


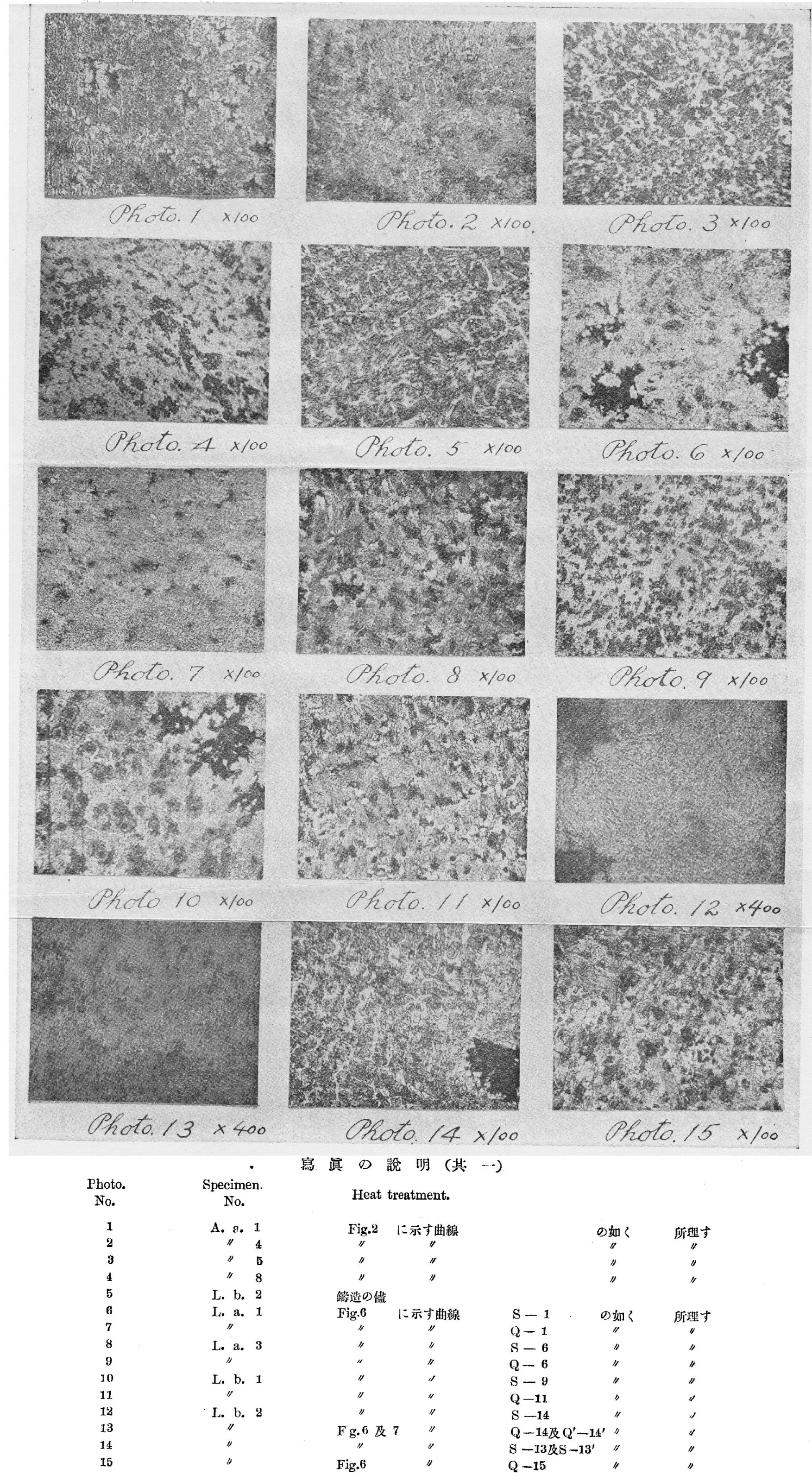




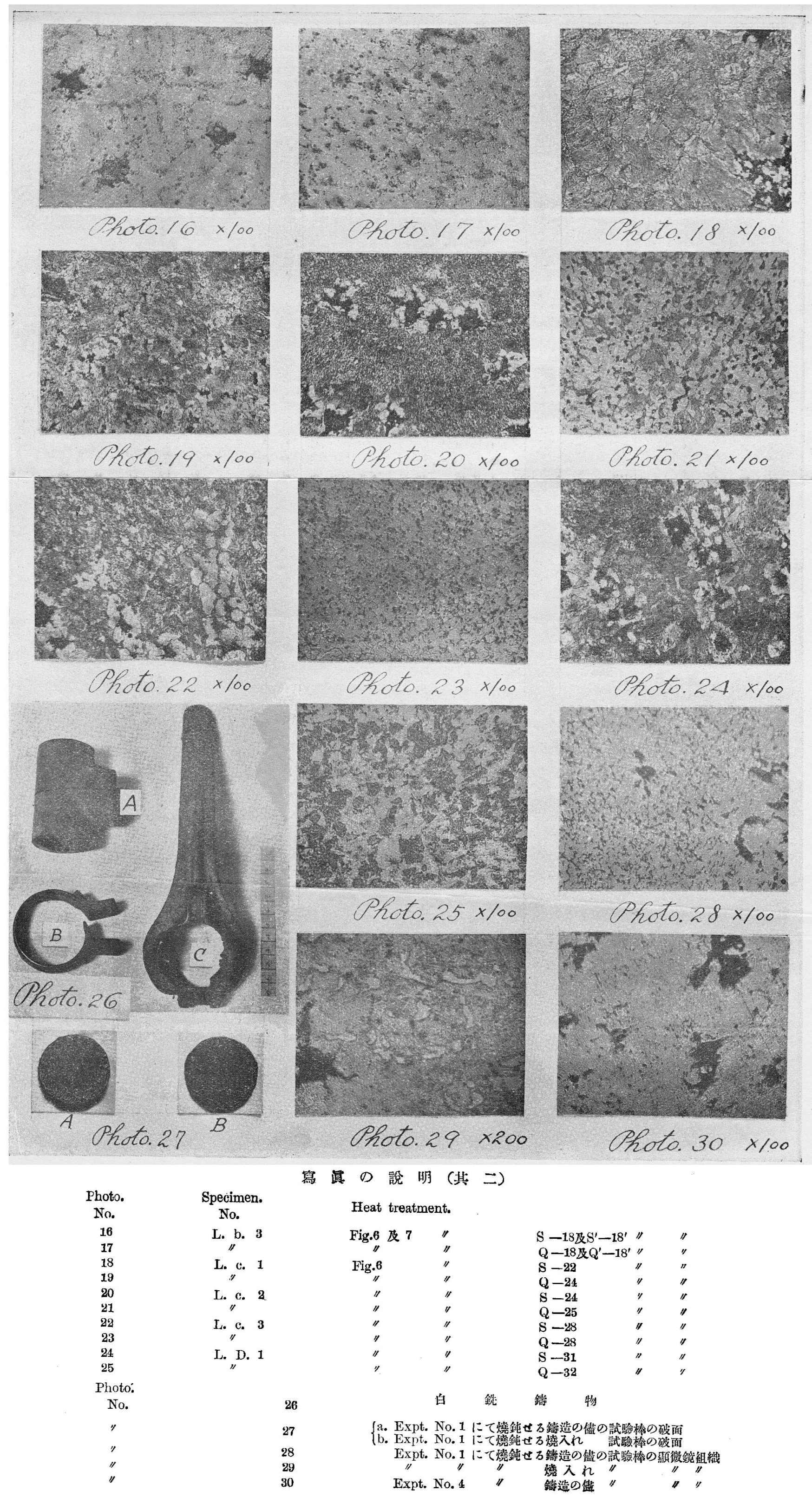




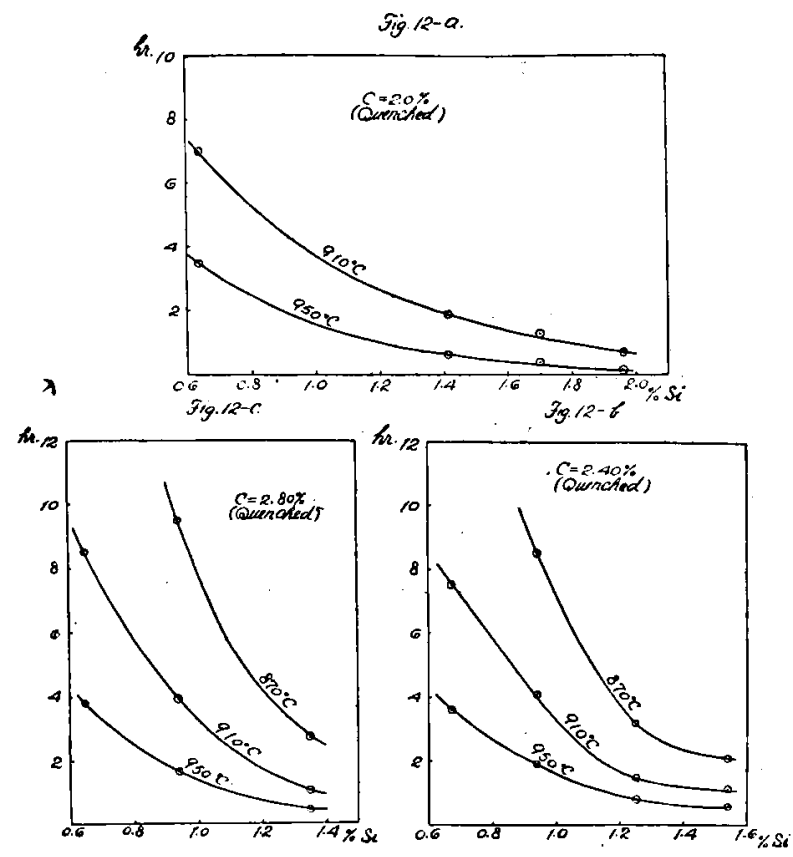

が其黑鉛化に及仿す影響如何に大なるかが容易に知られる。

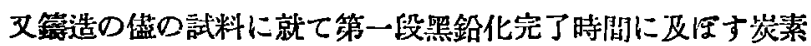
量の影響を見るに珪素量 $0.8 \%$ の白銑は第一段照鉛化溫度 $950^{\circ} \mathrm{C}$ に於て同完了時間は炭素量2〜24，\%までは變化がない が炭素量がそれ以上墦加するに從ひ幾分短樎される。珪素量 は $1 \%$ ○のにあつては第一段埋鉛化溫度 $950^{\circ} \mathrm{C}$ に於ては前 乙略同漛の關係が存在するが $910^{\circ} \mathrm{C}$ に於ては炭素量 $2 \%$ 以上，

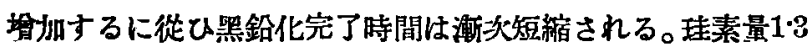
\%の白鉄にあつては黑鉛化完了時間怡んど炭素量の影響を
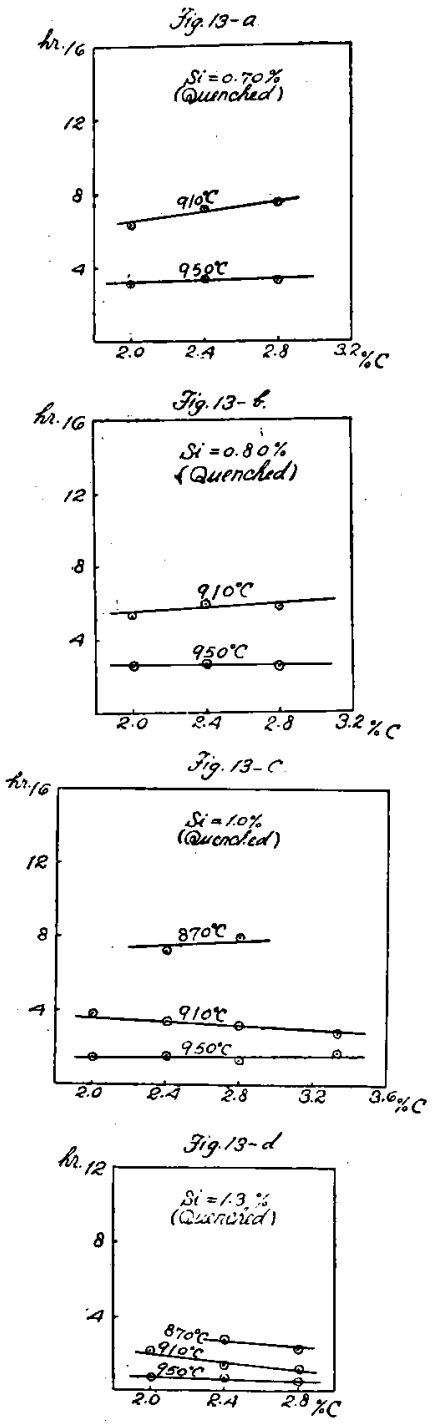

受けない。此等の諸點は菊田博士の賽騟結果とよく一致して居る，併し燒入れ試料に就ての此等の關 係は Fig. 13 に示す如く試料の舍炭量は第一段黑鉛化完了時間に殆んと關係ない事が知られる。

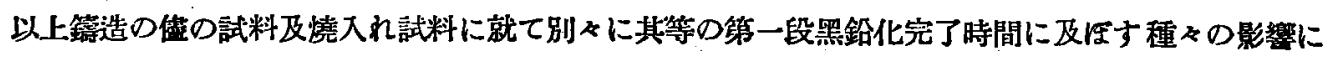
就て考察したのでするが、次に兩種白銑に就き比較して見ると一般に燒入れ試料の第一段埋鉛化完了

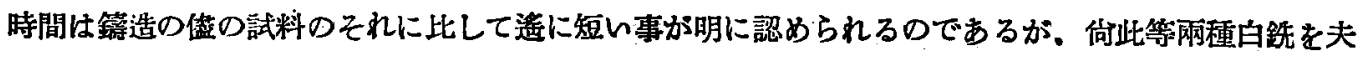

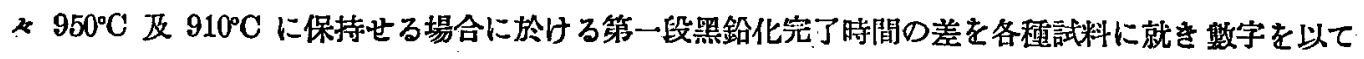
示せば Table 7 となる。師ち白銑を燒入れして後燒鈍する時は其第一段黑鉛化完了時間は鑄造の僬の 
炡料のそれの 1/3.5〜1/4 を以つて足りるのである。

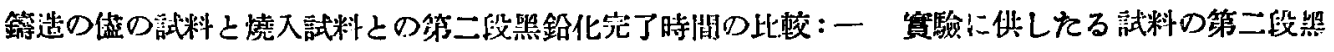
鉛化溫度及 Fig. 7 から第二段然鉛化完了時䦌を求むると Table 6 に示す如くなる。

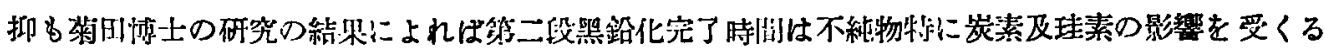

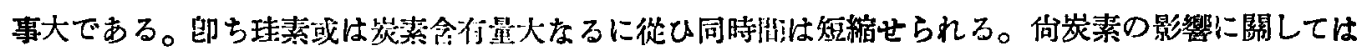

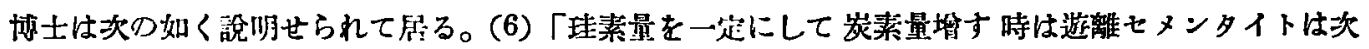

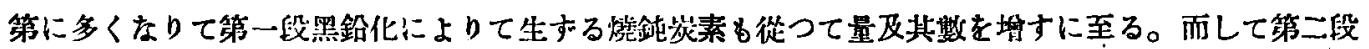
㫮鉛化は此炭素粒の周園より起りそれに遠き部分のパーライト，七メンタイトは次第に此炭素粘の周

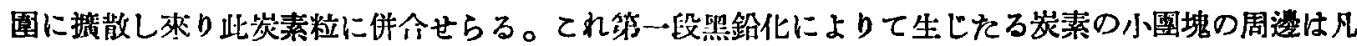

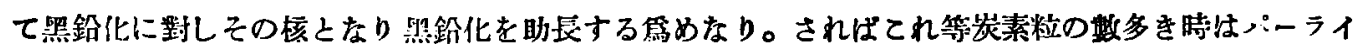

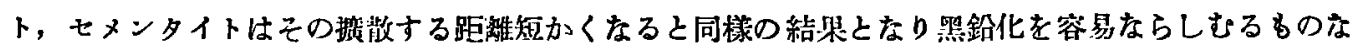

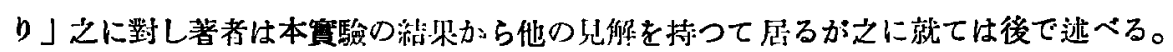

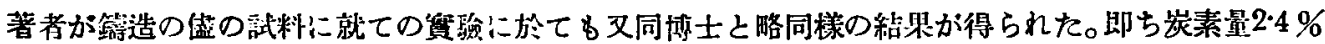

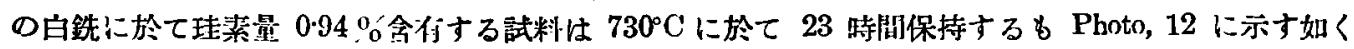

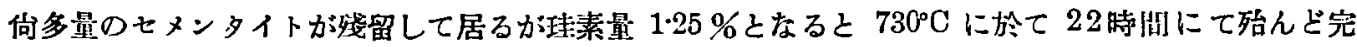

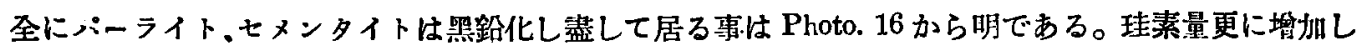
て $1.54 \%$ となる $740^{\circ} \mathrm{C}$ に於て 11 時間保持すれば充分である。及炭素量 $2.8 \%$ の白銑に於て珪素 量 $1.35 \%$ の䟼料は $740^{\circ} \mathrm{C}$ に於て 11 時間で充分である。若し珪素量 $1.54 \%$ 上なれ法てれより造に 短時間でパーライト，セメンタイトは熙鉛化し盡すであらら。

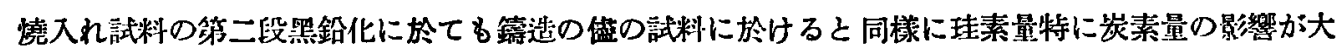

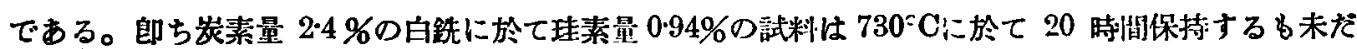
パーライト、ヒメンタイトの品鉛化不充分なる事は Photo. 13 からら明である。然るに珪素量 1.25\% の試驗は $730^{\circ} \mathrm{C}$ に於て約 5 時開にて第二段品鉛化は完了せられる。又珪素量 $1.54 \%$ となると約 3 時間 で充分である。炭素量 $2.8 \%$ ，珪素量 $1.35 \%$ の試料に至つては僅に 1.5 時閌なる短時間を以つて其次 ーライト、セメンタイトは完全に黑鉛化せられる。又炭素量 $3.3 \%$ ，珪素量 1.03\%の白銑にあつては $740^{\circ} \mathrm{C}$ に於て第二段照鉿化は 5 時問を以て終了する。てれを試料 L. b の場合に比すれば遙に短時間 とすべきである。台鋀造の俨の試料に於ても又燒入れ陚料に於ても第二段黑鉛化完了時間は第一段黑 鉛化溫度の影響を著しく受けない事が知られる。

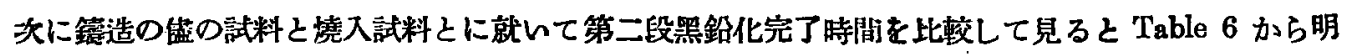

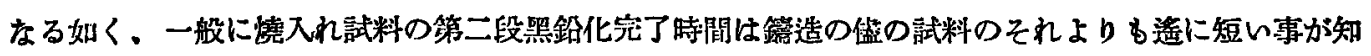
られる。此事實を数字的に示せば Table-7 に示す如くなる。而して白鉄の燒入れによりて第二段照鉿 化完了時間が短樎きれる割合は炭素量によつて著しく異り，例人ば炭素量 $2.4 \%$ 白銑に於て珪素量 


\section{Table7.}

\begin{tabular}{|c|c|c|c|c|c|c|c|c|c|c|}
\hline \multirow{2}{*}{\multicolumn{2}{|c|}{$\begin{array}{l}\text { Composition } \\
\text { of } \\
\text { Specimen } \\
\%\end{array}$}} & \multicolumn{4}{|c|}{$\begin{array}{l}\text { Annpaling time for complete } \\
\text { graphitization } \\
\text { in/ot stage. }\end{array}$} & \multicolumn{2}{|c|}{$\begin{array}{l}\text { Annoaling time } \\
\text { for Compote grophitization } \\
\text { in } 2 \text { ind Stage. }\end{array}$} & \multicolumn{3}{|c|}{$\begin{array}{l}\text { Ratio of asnealing time } \\
\text { for complete graphitization } \\
\qquad / / B\end{array}$} \\
\hline & & \multicolumn{2}{|c|}{$950^{\circ} \mathrm{C}$} & \multicolumn{2}{|c|}{$910^{\circ} \mathrm{C}$} & \multirow{3}{*}{$\begin{array}{l}\text { As cast. } \\
\text { hr. min. }\end{array}$} & \multirow{3}{*}{$\begin{array}{l}\text { Quenched } \\
\text { hr. min. }\end{array}$} & \multirow{2}{*}{\multicolumn{2}{|c|}{$\begin{array}{l}\text { in 1st stage } \\
\text { Annealing tampe }\end{array}$}} & \multirow{3}{*}{$\begin{array}{l}\text { in } \\
2 \text { nd } \\
\text { slage }\end{array}$} \\
\hline \multirow[b]{2}{*}{$C$} & \multirow{2}{*}{$S_{i}$} & \multirow{2}{*}{$\begin{array}{l}\text { As cast } \\
\text { (A) } \\
h_{0} \text {. min. }\end{array}$} & \multirow{2}{*}{$\begin{array}{l}\text { Qnenched } \\
\text { (B) } \\
\text { hr. min. }\end{array}$} & \multirow{2}{*}{$\begin{array}{l}\text { As cast } \\
\text { hr. (A) } \min .\end{array}$} & \multirow{2}{*}{$\begin{array}{l}\text { Quenched } \\
h_{\text {(B) }}^{(B)} \text { min. }\end{array}$} & & & & & \\
\hline & & & & & & & & $950^{\circ} \mathrm{C}$ & $910^{\circ} \mathrm{C}$ & \\
\hline 2,00 & $\begin{array}{l}0.70 \\
0.80 \\
1.00 \\
1.30\end{array}$ & $\begin{array}{rr}10 & 40 \\
6 & 0 \\
3 & 10 \\
\end{array}$ & $\begin{array}{ll}3 & 0 \\
2 & 30 \\
1 & 30 \\
0 & 40\end{array}$ & $\begin{array}{rr}14 & 0 \\
6 & 40\end{array}$ & $\begin{array}{ll}6 & 20 \\
5 & 20 \\
3 & 50 \\
2 & 10 \\
\end{array}$ & & & $\begin{array}{l}4.3 \\
4.0 \\
4.8\end{array}$ & $\begin{array}{l}3.7 \\
3.1\end{array}$ & \\
\hline 2.40 & $\begin{array}{l}0.70 \\
0.80 \\
1.00 \\
1.30\end{array}$ & $\begin{array}{cc}13 & 0 \\
11 & 0 \\
6 & 0 \\
3 & 10 \\
\end{array}$ & $\begin{array}{ll}3 & 20 \\
2 & 40 \\
1 & 30 \\
0 & 40\end{array}$ & $\begin{array}{rr}13 & 0 \\
6 & 20\end{array}$ & $\begin{array}{lr}7 & 10 \\
6 & 0 \\
3 & 30 \\
1 & 30\end{array}$ & 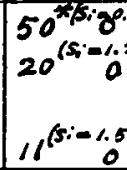 & 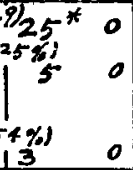 & $\begin{array}{l}3.9 \\
4.1 \\
4.0 \\
4.8\end{array}$ & $\begin{array}{l}3.5 \\
4.2\end{array}$ & $\begin{array}{c}(s /=0.9 \%) \\
2.9 \% \\
(s ;=1.25 \%) \\
4.4\end{array}$ \\
\hline 2.80 & $\begin{array}{l}0.70 \\
0.80 \\
1.00 \\
1.30\end{array}$ & $\begin{array}{cc}9 & 0 \\
4 & 30 \\
3 & 10 \\
\end{array}$ & $\begin{array}{ll}3 & 20 \\
2 & 30 \\
1 & 20 \\
0 & 30\end{array}$ & $\begin{array}{ll}9 & 30 \\
6 & 20\end{array}$ & $\begin{array}{ll}7 & 30 \\
5 & 50 \\
3 & 10 \\
1 & 10\end{array}$ & 11 & \%' & $\begin{array}{l}3.6 \\
3.4 \\
6.3\end{array}$ & $\begin{array}{l}3.0 \\
5.4\end{array}$ & 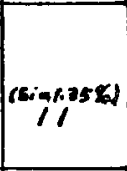 \\
\hline 3.33 & 1.03 & 530 & 150 & 1030 & 250 & & & 3.3 & 3.7 & \\
\hline 3.77 & 0.43 & (i97008) & 29703ej & & & & & $1 . \xi_{98}$ & & \\
\hline
\end{tabular}

*歷超

$1.54 \%$ の試料は燒入れによつて其第二段品鉛化完了時間は約 $1 / 4$ に短縮されるのであるが炭素量 2.8 \%の白銑に於て玙素量 1-35\%の陚料は焼入れによつて寞に $1 / 11$ に短縮されるのである。

白鉄の燒入れによつて第二段黑鉿化完了時閆がかく著しく短縮される事實は實地應用上重要なる 現象であるが其理由は次の如くに釋明せられる。

前に述べた如く燒入れ試料に於ては第一段黑鉛化に與るセメンタイトの量は篟造の㑺の試料のそれ に比して遥に多量で從つて前者に於ける第二段㫮鉛化に與るセメンタイトの量は後者に於けるよりる 迸に小量となるものでする。故に若し兩種白銑の第二段黑鉛化が同一の速度を以て進行すれば當然㫮 鉛化に與るとメンタイトを少量含有する燒入れ試料の第二段黑鉛化が他に比して急速に完了せらる可 きである。從て燒入れ試料に於ては炭素量が多い程第二段黑鈁化に與るセメンタイトの量が小となる が故に其第二段照鉛化時間は短縮せられるのである。

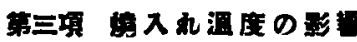

ての賽驗に用ひた辣料の成分は Table 8 に示す通りである。 
Table 8

\begin{tabular}{|c|c|c|c|c|c|c|}
\hline \multirow{2}{*}{$\begin{array}{c}\text { Specimen } \\
\text { No. }\end{array}$} & \multicolumn{6}{|c|}{ Composition } \\
\cline { 2 - 7 } & $\mathrm{C}$ & $\mathrm{Si}$ & $\mathrm{Mn}$ & $\mathrm{P}$ & $\mathrm{S}$ & $\mathrm{Cu}$ \\
\hline $\mathrm{P}$ & $2 \cdot 80$ & $1 \cdot 21$ & $0 \cdot 28$ & $0 \cdot 193$ & 0.072 & 0.17 \\
\hline
\end{tabular}

試料を前述の方法を以て霾くの溫度より $24^{\circ} \mathrm{C}$ 水中に嵒入れしたる後之を $920^{\circ} \mathrm{C}$ 及 $740^{\circ} \mathrm{C}$ に保持 して第一段黙鈴化完了時閒及第二段熟鉛化完了時間を测定した。其絬果は Fig. 14. a. b. 及 Table 9 に示してある。a圖は第一段黑鉛化、b 圖は第二段照鉛化の進行の狀態を表はす。

Table 9

\begin{tabular}{|c|c|c|c|c|c|c|c|}
\hline \multirow{2}{*}{\multicolumn{2}{|c|}{$\begin{array}{c}\text { Specimen } \\
\text { No. }\end{array}$}} & \multirow{2}{*}{$\begin{array}{c}\text { Quenching } \\
\text { temperature } \\
\left({ }^{\circ} \mathrm{C}\right)\end{array}$} & \multicolumn{4}{|c|}{$\begin{array}{l}\text { Time required to complete the } \\
\text { graphitization }\end{array}$} & \multirow{2}{*}{ Remarks } \\
\hline & & & \multicolumn{2}{|c|}{ 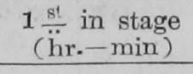 } & \multicolumn{2}{|c|}{$\begin{array}{l}2 \frac{\text { nd }}{\ddot{h}} \text { in stage } \\
(\text { hin. })\end{array}$} & \\
\hline P. a. & 1 & 850 & 1 & 50 & 4 & 0 & \multirow{3}{*}{$\begin{array}{l}\text { 凡て } 24^{\circ} \mathrm{C} \text { の水 } \\
\text { 龙燒入れ劑とす }\end{array}$} \\
\hline " & 2 & 920 & 0 & 50 & 1 & 30 & \\
\hline "I & 3 & 1,000 & 0 & 50 & 1 & 0 & \\
\hline
\end{tabular}

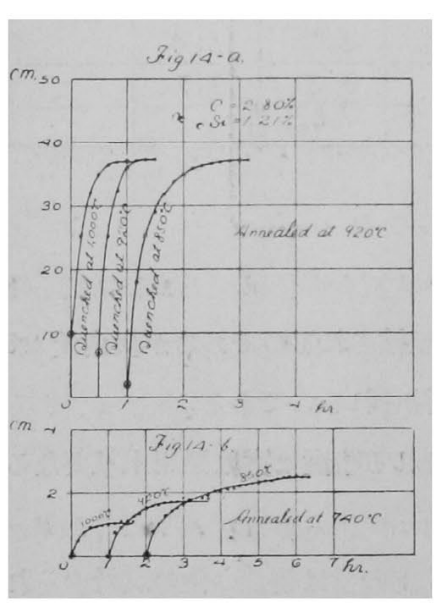

上の暂驗の淑果によると此場合でも又燒入れ溫度が高い程第一段 熙鉛化は容易に進行し其沾管第二段黑鉛化に與るパーライトの量は

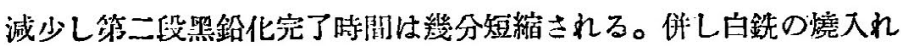
溫展の影饗は左程著しいるのではない。

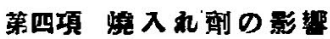

此研究に於ては Table 8 に示す成分を有する試料を用ひた。

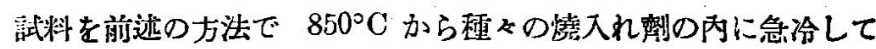
後 $920^{\circ} \mathrm{C}$ 及 $740^{\circ} \mathrm{C}$ に保持して其㫮鉛化狀態を測定した。其結果 は Fig. $15 \mathrm{a}$ 及 b 亚に Table 10 に示してある。a 圖は第一段黑

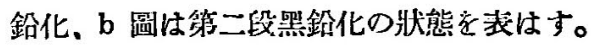

Table 10

\begin{tabular}{|c|c|c|c|c|c|c|c|c|c|}
\hline \multirow{2}{*}{$\begin{array}{c}\text { Specimen } \\
\text { No. }\end{array}$} & \multirow{2}{*}{\multicolumn{3}{|c|}{$\begin{array}{l}\text { Quenching } \\
\text { medium }\end{array}$}} & \multirow{2}{*}{$\begin{array}{c}\text { Temp. of. } \\
\text { quenching } \\
\text { medium }\left({ }^{\circ} \mathrm{C}\right)\end{array}$} & \multicolumn{4}{|c|}{$\begin{array}{l}\text { Time required to complete the } \\
\text { graphitization }\end{array}$} & \multirow{2}{*}{ Remarks } \\
\hline & & & & & \multicolumn{2}{|c|}{$\begin{array}{l}1 \frac{\mathrm{st}^{+}}{\mathrm{h}} \text { in stage } \\
\text { (hr.-min.) }\end{array}$} & \multicolumn{2}{|c|}{ 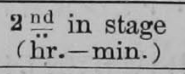 } & \\
\hline P. b. 1 & 食 & 監 & 水 & -10 & 1 & 30 & 3 & 0 & \\
\hline "I 2 & & 水 & & 25 & 1 & 40 & 3 & 30 & 凡て $850^{\circ} \mathrm{C}$ より \\
\hline "I & & 水 & & 80 & 2 & 30 & 2 & 30 & 燒入れす \\
\hline " & 荣 & 種 & 油 & 28 & 6 & 0 & 9 & 0 & \\
\hline
\end{tabular}


白鉄の黑鉛化に關する新現象と其黑心可鐉鏄物工業への應用に就て 1025
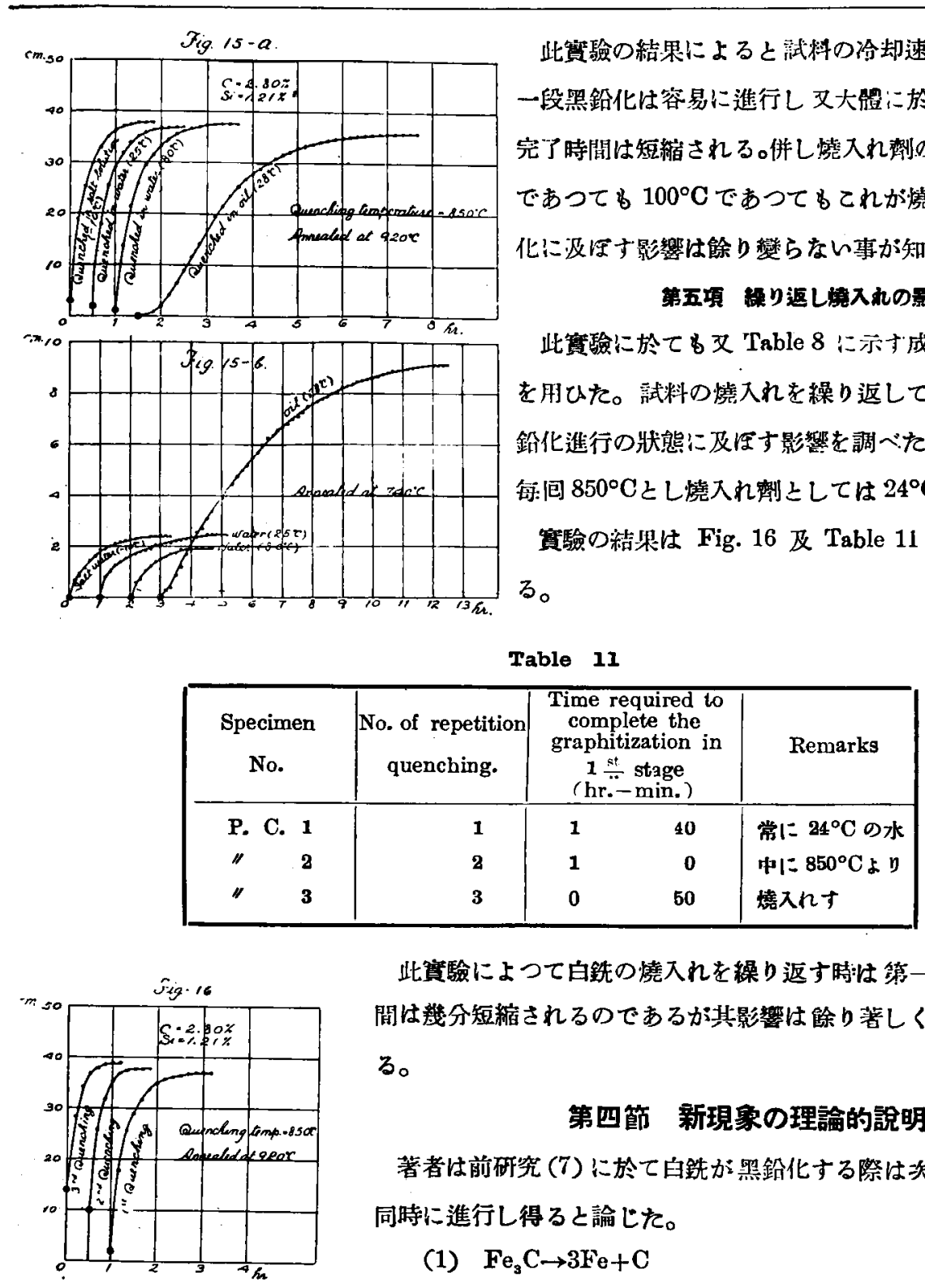

此實驗によつて白銑の燒入へを繰り返す時は第一段黑鉛化完了時 閶は䋐分短縮されるのでするが其影響は餘り著しくない事が知られ る。

\section{第四管 新現象の理論的說明}

著者は前研究 (7)に於て白鉄が照鉛化する際は次の 2 つの作用が 同時に進行し得ると論じた。

(1) $\mathrm{Fe}_{3} \mathrm{C} \rightarrow 3 \mathrm{Fe}+\mathrm{C}$

（2）含炭量大なるォーステナイト $\rightarrow$ 含㞸量小なるォーステナ $1++\mathrm{C}$

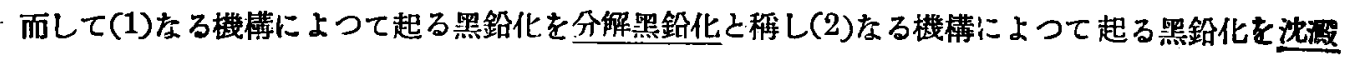
黑鉿化と名付けた。

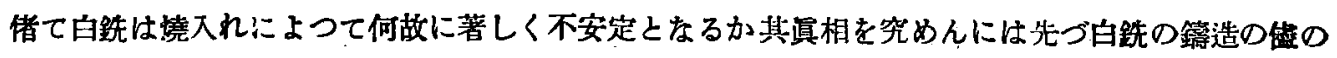
ものと燒入れせるるのとに就て其組織を比較研究すべきである。 


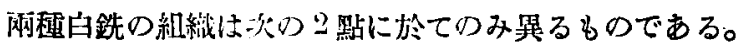

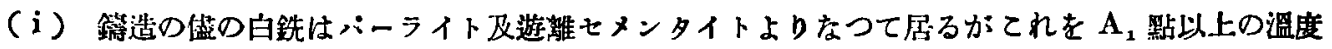
に扠熱する時はパーライトはオーステナイトに變化する。

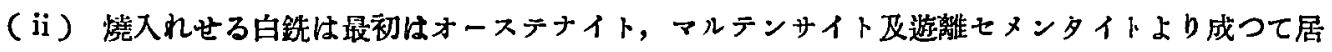
るがてれを燒鈍するに當りオーステナイト及マルテンサイトは先づハーライト(トルースタイト及ン

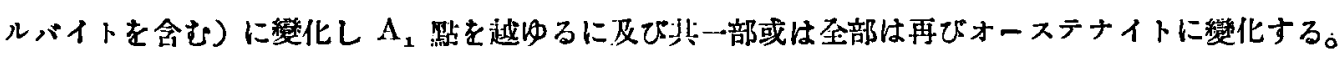

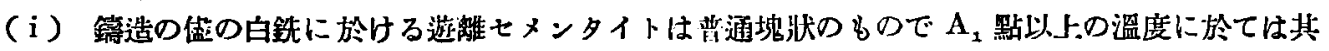
周圐は Fig. $17 \mathrm{a}$ 中 $\mathrm{e}$ に示す如く悉くオーステナイトに接解して居る。 sig. $>7$.

(a)

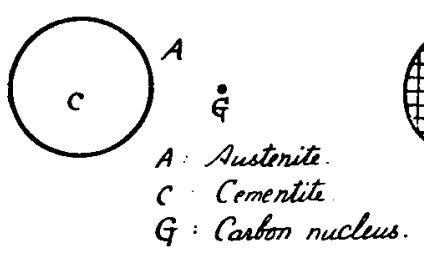

（ii）燒入れせる白鉄に於ける遊離セメンタイト

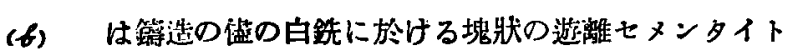
が堯入れの䍃めに種くの方向に應力を受けて其位通 に於て細に破壞され從つて Fig. $17 \mathrm{~b}$ 中 $\mathrm{c}_{2}$ の如き 自由表面によつて包まれたる多数の緇いたメンタイ トの集合より成つて居るものである。何となれば白 銑の籍造の睢の組織はパーライト基質によつて包ま

れたる遊離セヌンタイト或は遊蜼セメンタイトによつて包まれたるパーライトより成つて居り、此ハ ーライトの部分は燒入れによつてオーステナイトよりマルテンサイトとをり非常に膨脹するものであ

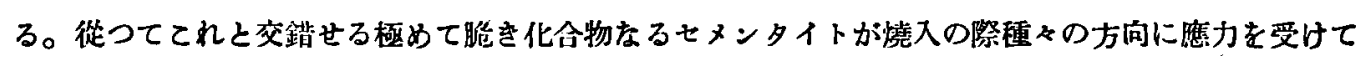

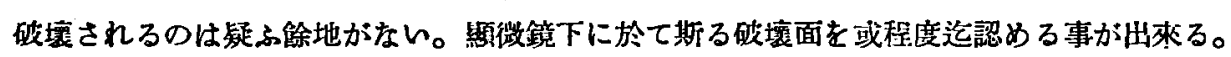

以上二方面から本現象の原因を究めて見るこ本現鮽は(1)に迅べてる事項によつては了解し難く(2) に逃べたる事實によつて容易に說明する事が出東るのである。

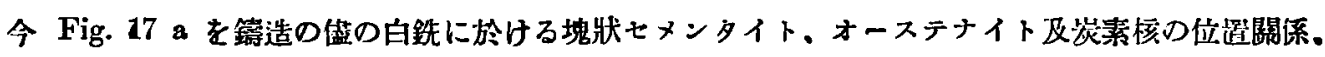
Fig. 17 b を燒入れ白銑に於ける破壞細分されたるセメンタイト，オーステナイト及炭素核の位通閶 係を表はするすとする。a 圖に於てセメンタイト c は周邀は凡てオーステナィトによつて包まれて 容易にオーステナイトに撗散し得る位逢にあるが， b 圖に於てはオーステナイトに直接接触せるセメ ンタイト粒は $\mathrm{c}_{1}$ の如く此セメンタイト粒の群の周䢬に位通せるものに限り, 其內部に得在せる多数 のセメンタイト粒 $c_{2}$ の如きは何れる自的表面を有して居るが故に單獨に分解し得る位政にある。從

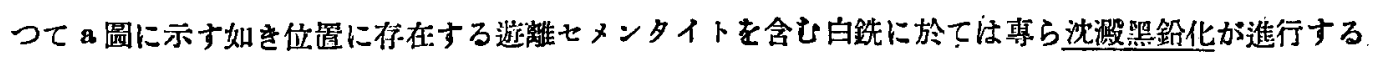

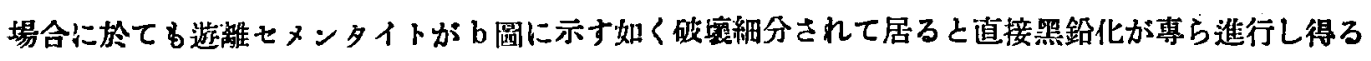
ものである。而して自由表面を有するセxンタイトはオーステナイトにて包まるるセヌンタイトに比 
して分解し易く且つ燒入れ自鉄に於けるセメンタイト粒の大さが籍造の盐の白銑のそれに比して遙に

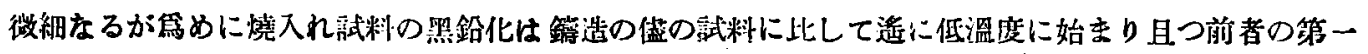
段黙鉊化は媵者のそれに比して遙に短時阴に完結せられる。

本現象を斯くの如く說明する事によつて本筫䀫によつて得られれ種くの現象を凡て容易に了解する 事加出來る。

即ち燒入れ盜度が空くなる程燒入れに與るオーステナイトの量が多くなり。てれがセメンタイトに

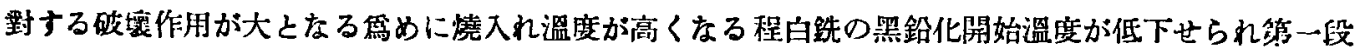
黑化完了時临が短縮せられる。

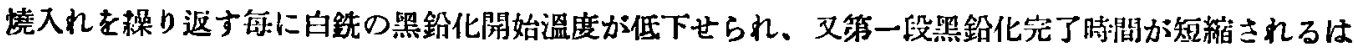

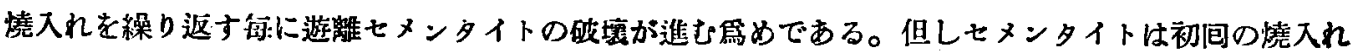

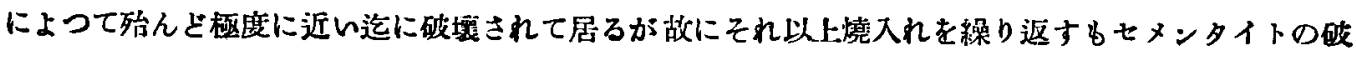
境は狳り非行しなく從つて2回以上燒入れを繰り返する初间の燒入れ程影響せぬのである。

燒入れの際の陚料の给却速度は丁度オーステナイトの全部をマルテンサイトに止め得る程度が一番 有效であつて第二節第三項及第三節第四項に於ける筫唶の洁果も此原则に從つたものに外ならない。

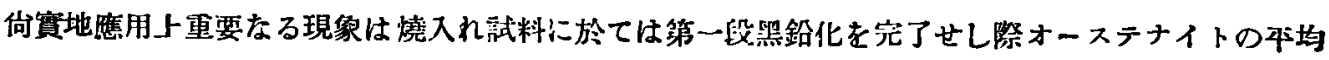
炭素量は一般に䇺造の睢の試料に於けるそれよりる邀に少く邓之には炭素の影響が著しいてとである が、てれは前者に於ては主として分解㫮鉛化が進行し後者に於ては主として䧱潜照鉛化が進行したる 結果に他ならない。分解黑鉛化によりて生じたるオーステナイトの平均合炭量は战料の炭素含有量の 影響を受け其会有量大なる程オーステナイトの本均合炭量が小となる倾向あるは言を須たない。白銑 の燒入れによつて第二段黑鉛化完了時閉が著しく短縮されるのは骂に燒入れによつて第一段哇鉙化が 主として分解黙鉊化の機構によつて完了せられたる結果てれに與つたセメンタイトの量が著しく多量 になり逆にオーステナイトの平均舍炭量少となり從つて第二段㫮鉛化に與るパーライト，七メンタイ トの量が著しく少量となりたる結果による事は前に述べた通りである。籍造の㑺の試料に於ても沈澱 墨鉛化と同時に分解哇鉛化が勿論進行するものである。而して分解㫮鉛化に與る遊離セメンタイトの

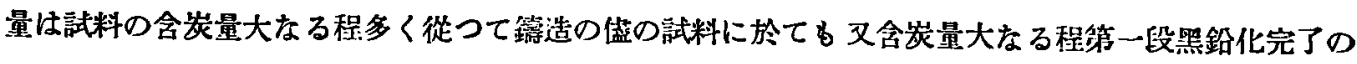
際に於けるオーステナイトの平均合炭量小となり從つて第二段熙鉛化に與るパーライト、セメンタイ トの量從つて第二段㫮鉛化完了時間は試料の含炭量が大となる程小となるるのと若へられるのである

\section{第二章 新現象の䆓地應用に關する實驗 第一節＼cjkstart杬戻炭素の据散に闒するニ三の實驗}

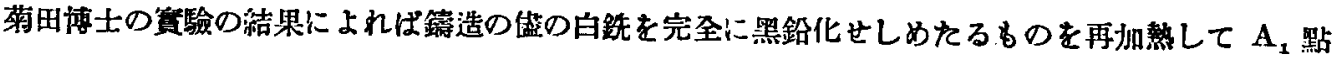

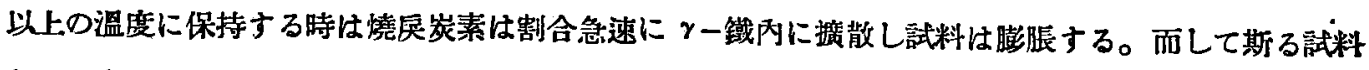

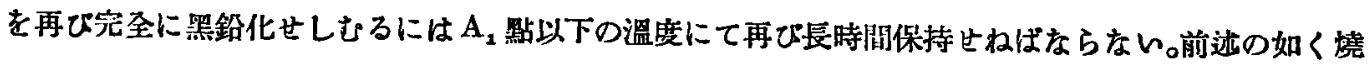




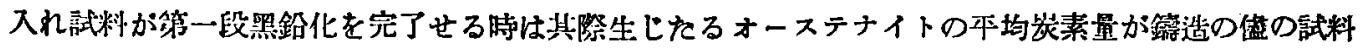

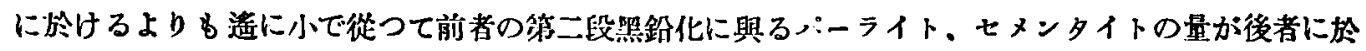
けるそれよりる小で其洁果前者に於ける第二段熙鉛化完了時間は後者のそれよりも短いと云ふ特徵が

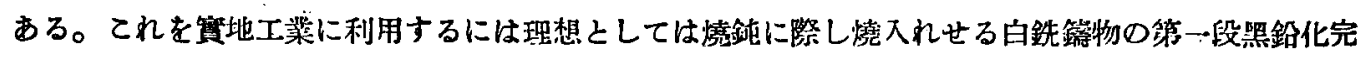

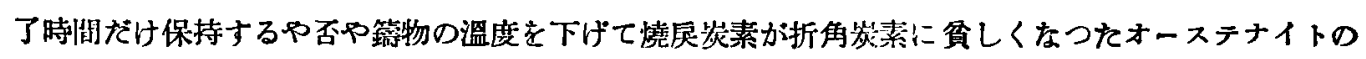
內に再び撗散する機會をなからしむ可きであるが實際問題としては斯る操業方法は甚だ困難である。

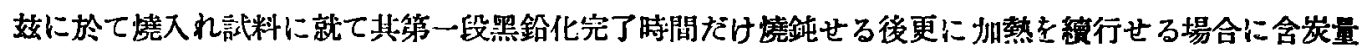

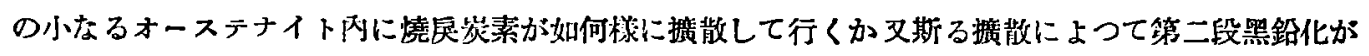
如何に影響を受くるかは本現象を賽地に應用するに虽つて重要なる問題である。

ての貝驗方法としては先づ Table 6 に示す試料 I. C. 3 を 4 個探りて前章に述べたる方法によ りて凡て $850^{\circ} \mathrm{C}$ より $23^{\circ} \mathrm{C}$ の水中に焼入れし a は $900^{\circ} \mathrm{C}$ に保持して其第一段㫮鉙化が完了せられ

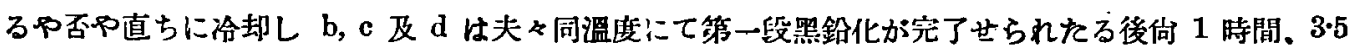
時關, 6 時間同溫度に保持して後冾却し凡て一旦 $\mathrm{Ar}_{1}$ 變化を完了せしめ晌 $700^{\circ} \mathrm{C}$.迄椧却せしめたる

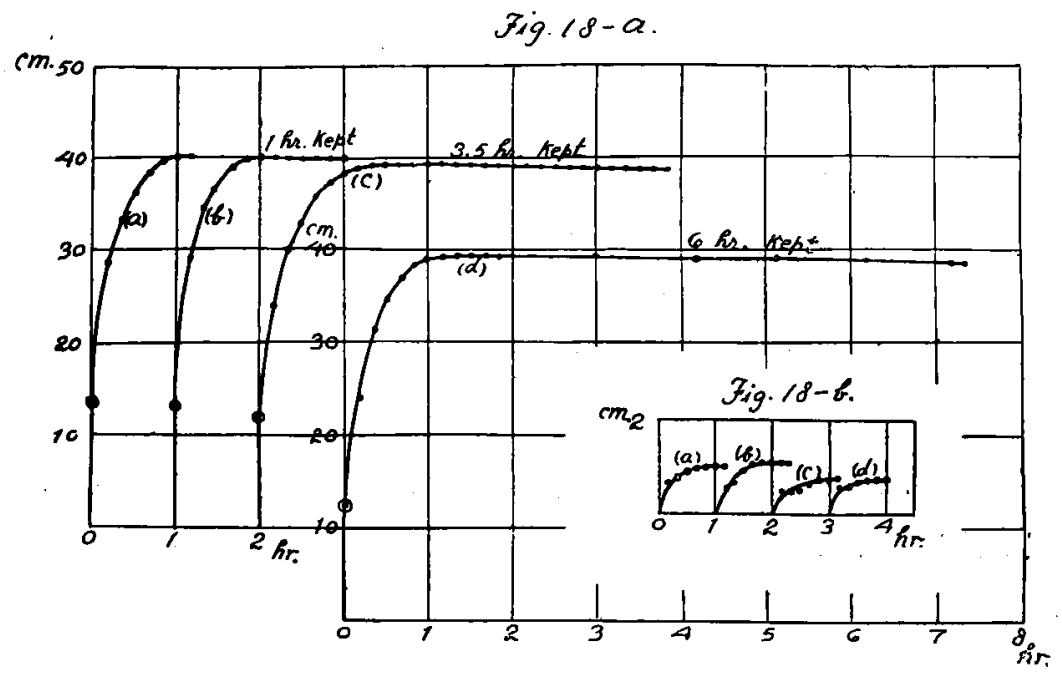

後再び $740^{\circ} \mathrm{C}$ 迄溫度を上げ同溫度に於て各試料の第二段㫮鉛化の狀態を調べれ筫驗の結果は Fig. 18 a; b に示す如くである。a圆は第一段㷦鉛化及加熱續行の曲線で b 圆は第二段黑鉛化曲粕である。

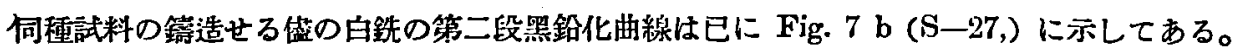

此實驗の結果によると試料を其第一段熙鉊化完了時間以上加熱を續行するる少しる膨脹せすして却

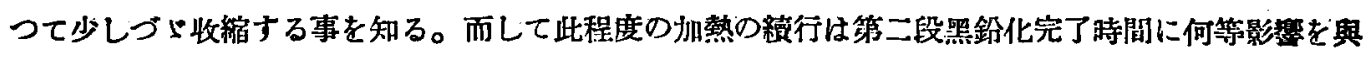

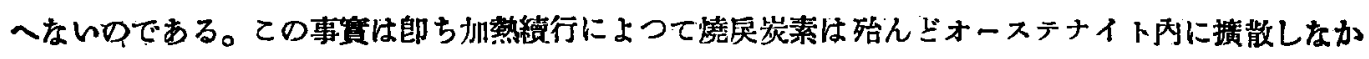
つた事を示するのである。 

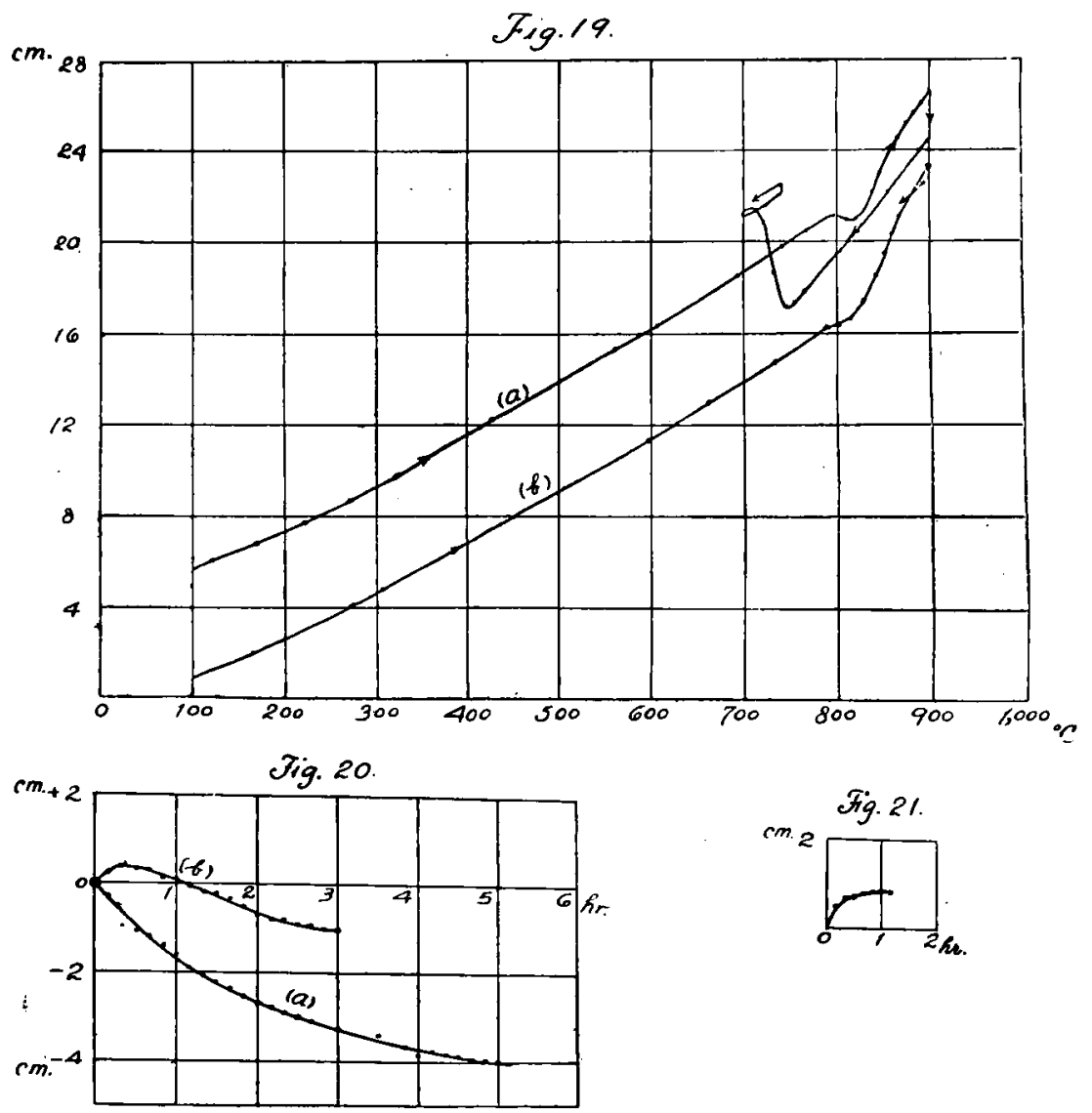

次に完全に品鉛化せる $\mathbf{C}$ 試料を探り之を熱膨脹測定器によつて再加熱して $900^{\circ} \mathrm{C}$ に達せしむ同溫 度に 5 時間保持して後冷却し第二段品鉛化の狀態を調查したるに Fig. 19-a, Fig. 20 a,及 Fig. 21 に示す如き曲線を得た。Fig. 19-a は試料の加熱及冷却曲線である。加熱に際し $\mathrm{A}_{1}$ 以上の溫度に 達すると試料が異狀に膨脹するのは燒杘炭素が $\gamma$ 一鐵內へ摭散するによるのですら5。Fig. 20-aは $900^{\circ} \mathrm{C}$ に保持した間に於ける試料の延びの變化を示す。此賽驗の結果によると試料は蒾田脖士の賽驗 の結果に反して次第に收縮する。Fig. 21 は $740^{\circ} \mathrm{C} に$ 於りる第二段㫮鉛化曲線を示す。即ち此試料は

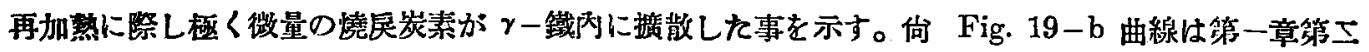
節第四項に於て述へたる實驗に於て完全黑鉛化せしめたる試料 M. b. 3 を再扣熱せる際に於ける扣 熱曲線を示し Fig. $20-\mathrm{b}$ 曲線は同試料を $900^{\circ} \mathrm{C}$ に 3 時間保持の間に於ける延びの變化を示す。此 場合に於ては最初の間は少しく瞦脤するが其後は矢張り收縮する。此の收縮は何心基因するやは將來 の研究に街つものである。 


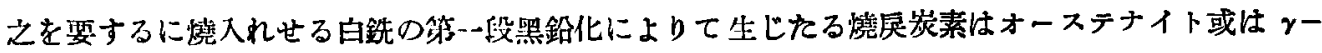

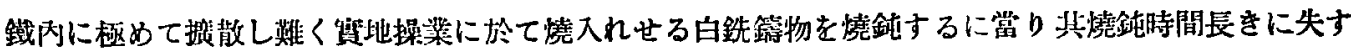
るも第二没品鉛化完了時間には關係なき事考確めたのである。

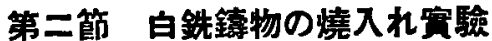

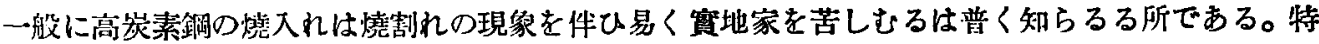
に白銑の如き多量の遊離セメンタイトを含みたるものは其燒入れに際し燒割れを生じ易をは想像に難 くない。此事賽が本現像を實地に應用するに當りて起る一大難關である。

本現象を筫地に應用する場合を考ふるに白鉄籍物は之を成る可く急速に所要の溫度迄加熱し可成短

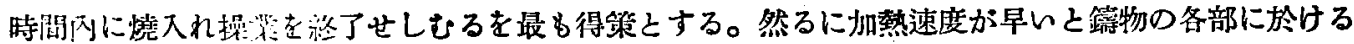

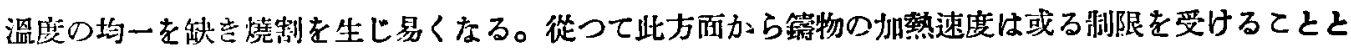
なる。

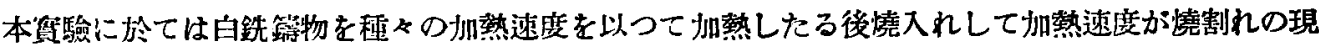

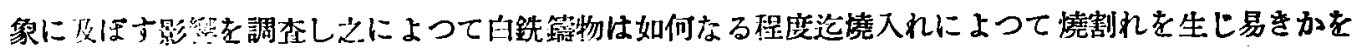
定性的に知るを主眼としたのである。

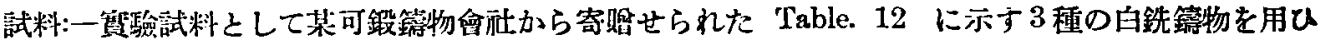
た。Photo. 26 は此等試驗の外觀を示す。

Table 12

\begin{tabular}{|c|c|c|c|c|}
\hline \multirow{2}{*}{$\begin{array}{c}\text { Sample } \\
\text { No }\end{array}$} & \multirow{2}{*}{$\begin{array}{l}\text { Kind of } \\
\text { Sample }\end{array}$} & \multicolumn{2}{|c|}{ Compsition (\%) } & \multirow{2}{*}{ Remarks } \\
\hline & & C & $\mathrm{Si}$ & \\
\hline$A-\mathbf{I}$ & Photo. 26-A & $2 \cdot 87$ & $1 \cdot 06$ & 清津面各有寸 \\
\hline $\mathbf{A}-\mathbf{I}$ & do. & do. & do. & 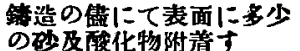 \\
\hline B & photo. $26-\mathrm{B}^{\circ}$ & $2 \cdot 74$ & 1.03 & 清淨面杂有す \\
\hline $\mathrm{C}$ & Photo. $26-\mathrm{C}$ & do. & do. & 清浮面方有す \\
\hline
\end{tabular}

馩驗の方法:一マツフルの容量 $190 \mathrm{~mm} \times 130 \mathrm{~mm} \times 350 \mathrm{~mm}$ を有するホスキン盢の中央に 焙燒血を 置き其上に試料を乘せて加熱した。其溫度は熱電對の接合點を丁度試料の上に置いて測定した。燒入

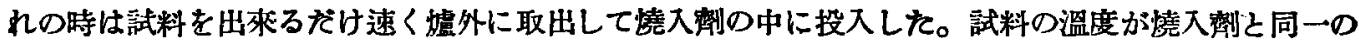
温度になるのを待つて取り出し直ちに試料の表面を乾いた木綿片を以て拭を其表面に附着せる燒入放

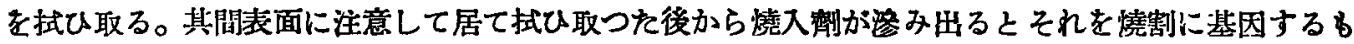
のとしたのである。

實驗の結果:一實驗の結果を總括すると Table 13 に示す如くである。此表に於て 
Table 13

\begin{tabular}{|c|c|c|c|c|}
\hline \multirow{2}{*}{$\begin{array}{c}\text { Sarple } \\
\text { No. }\end{array}$} & \multirow{2}{*}{$\begin{array}{c}\text { Method of heat } \\
\text { treatment }\end{array}$} & \multirow{2}{*}{$\begin{array}{l}\text { Quenching } \\
\text { Medium }\end{array}$} & \multicolumn{2}{|c|}{ Nos. of Specimen } \\
\hline & & & $\begin{array}{c}\text { No cruck was } \\
\text { produced }\end{array}$ & $\begin{array}{l}\text { Cruck was } \\
\text { produced }\end{array}$ \\
\hline $\mathrm{A}-\mathrm{II}$ & A & 水 $\left(25^{\circ} \mathrm{C}\right)$ & \begin{tabular}{|l|}
3 \\
1 \\
\end{tabular} & \\
\hline$A-I I$ & B & do. & 4 & \\
\hline A-II & $\mathrm{C}$ & do. & 4 & \\
\hline$A-I I$ & $\mathrm{D}$ & do. & 4 & \\
\hline${ }^{A-I I}$ & $\mathbf{E}$ & do. & $\begin{array}{l}4 \\
1\end{array}$ & \\
\hline $\begin{array}{c}\mathbf{A - I I} \\
\mathbf{C} \\
\mathbf{C}\end{array}$ & $\mathbf{F}$ & do. & $\begin{array}{l}6 \\
6 \\
3 \\
\end{array}$ & 4 \\
\hline$A-I$ & $\mathrm{G}$ & 荣種油 $\left(24^{\circ} \mathrm{C}\right)$ & 6 & \\
\hline $\mathbf{A}-\mathbf{I}$ & A & 水. $\left(25^{\circ} \mathrm{C}\right)$ & & 5 \\
\hline
\end{tabular}

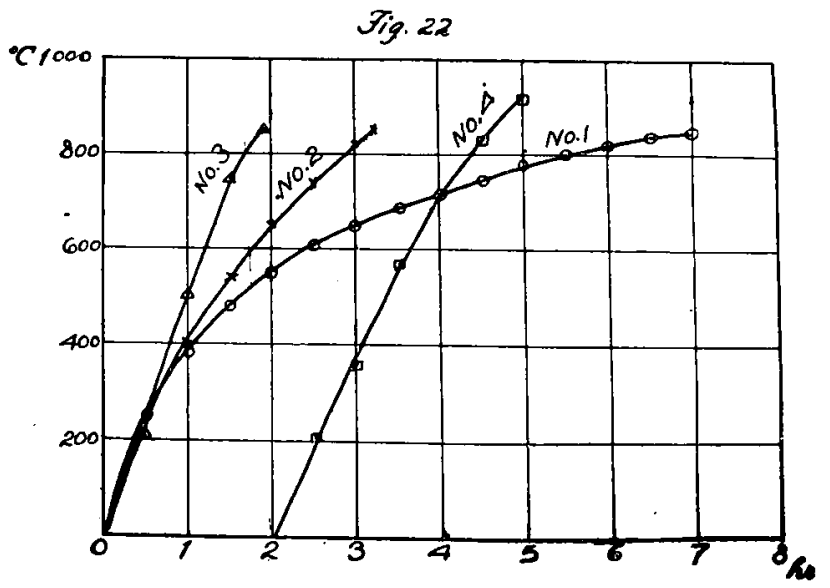

A は試料を Fig.22 加熱曲線 No.1 に沿ひて加熱し $850^{\circ} \mathrm{C}$ に達するや否や暁入れした。 B は試料を Fig.22 加熱曲線 No.2 に沿ひて加熱し $850^{\circ} \mathrm{C}$ に達するや否や焼入れした。 C は試料を Fig.22 加熱曲線 No.3 に沿ひて加熱し $850^{\circ} \mathrm{C}$ に達するや否や燒入れした。 $\mathrm{D}$ 注試料を Fig.22 加熱曲線 No.4 に沿ひて加熱し 920C に達するや否や燒入れした。

E は試料を $850^{\circ} \mathrm{C}$ に加熱せる曥冈に入れ其溫度が $850^{\circ} \mathrm{C}$ に澾してから 10 分間同溫度に保持して 後燒入れした。

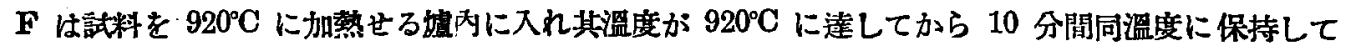
後燒大れした。 


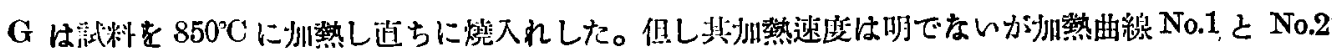
との中同に鹰す。

以上の絃界によるとPhoto. 26 B,C の如き簡單な形の篟物は其加熱速度が極めて大であつたに不扬

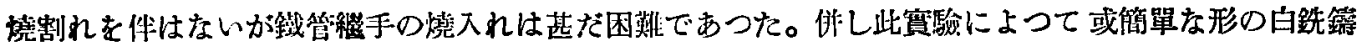
物なれば常溫の水中に燒割れを生せしめないで毞入れする事が出來る事を確め得たのである。

\section{第三節＼cjkstart新現象の應用によりて製造せる黑心可銠鑄 鐵の抗張力及延伸率に就て}

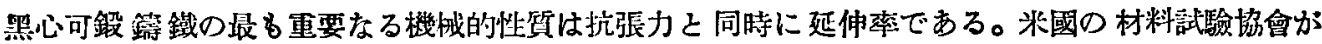

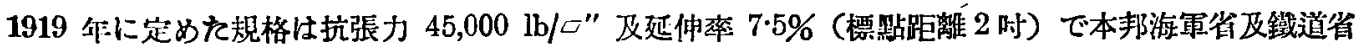

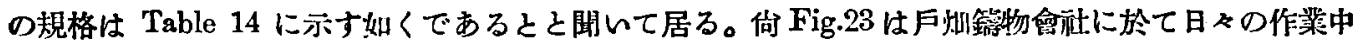

Table 14

\begin{tabular}{|c|c|c|}
\hline & $\begin{array}{c}\text { Tensile strength } \\
\text { ton } /{ }^{-\prime \prime}\end{array}$ & $\begin{array}{c}\text { Elongation } \\
\left.02^{\prime \prime}\right)\end{array}$ \\
\hline 海更省 & 18 & 8 \\
\hline 犝道省 & 2) & 5 \\
\hline
\end{tabular}

Fig. 23.

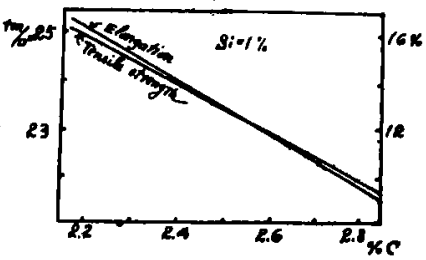

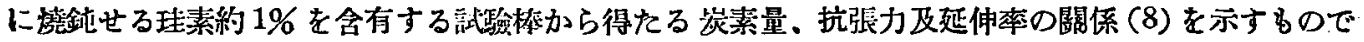
ある。此試簽に用ひた試驗棒は著者が本研究に用ひた試驗棒の寸法と全く同じである。

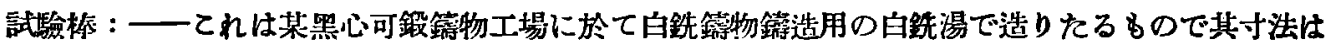
Fig. 24 に示し其成分は Table 15 に示してある。

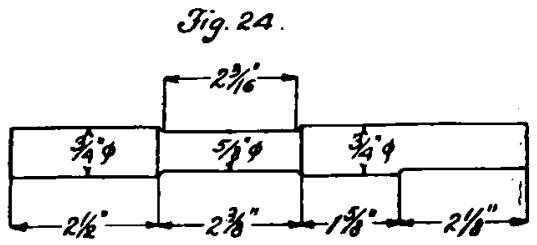

\begin{tabular}{|c|c|c|c|c|}
\hline $\mathrm{C}$ & $\mathrm{Si}$ & $\mathrm{Mn}$ & $\mathrm{P}$ & $\mathrm{S}$ \\
$(\%)$ & $(\%)$ & $(\%)$ & $(\%)$ & $(\%)$ \\
\hline 2.36 & 1.02 & 0.28 & 0.136 & 0.046 \\
\hline
\end{tabular}

燒入れ方法 : 一一試驗棒を燒入れ筫驗に䏳ひたるマッフル嘘に入れ Fig.22 加熱曲線 No.2 なる速度

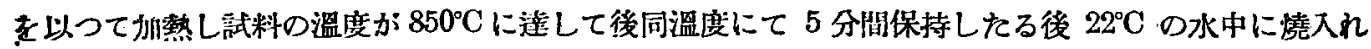
した。

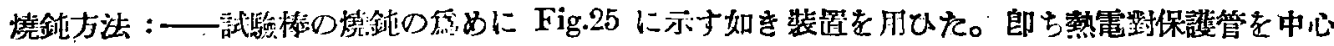

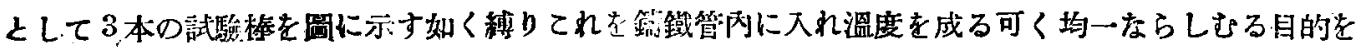




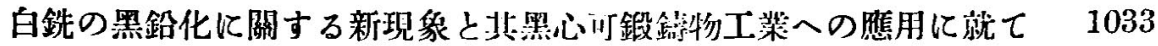
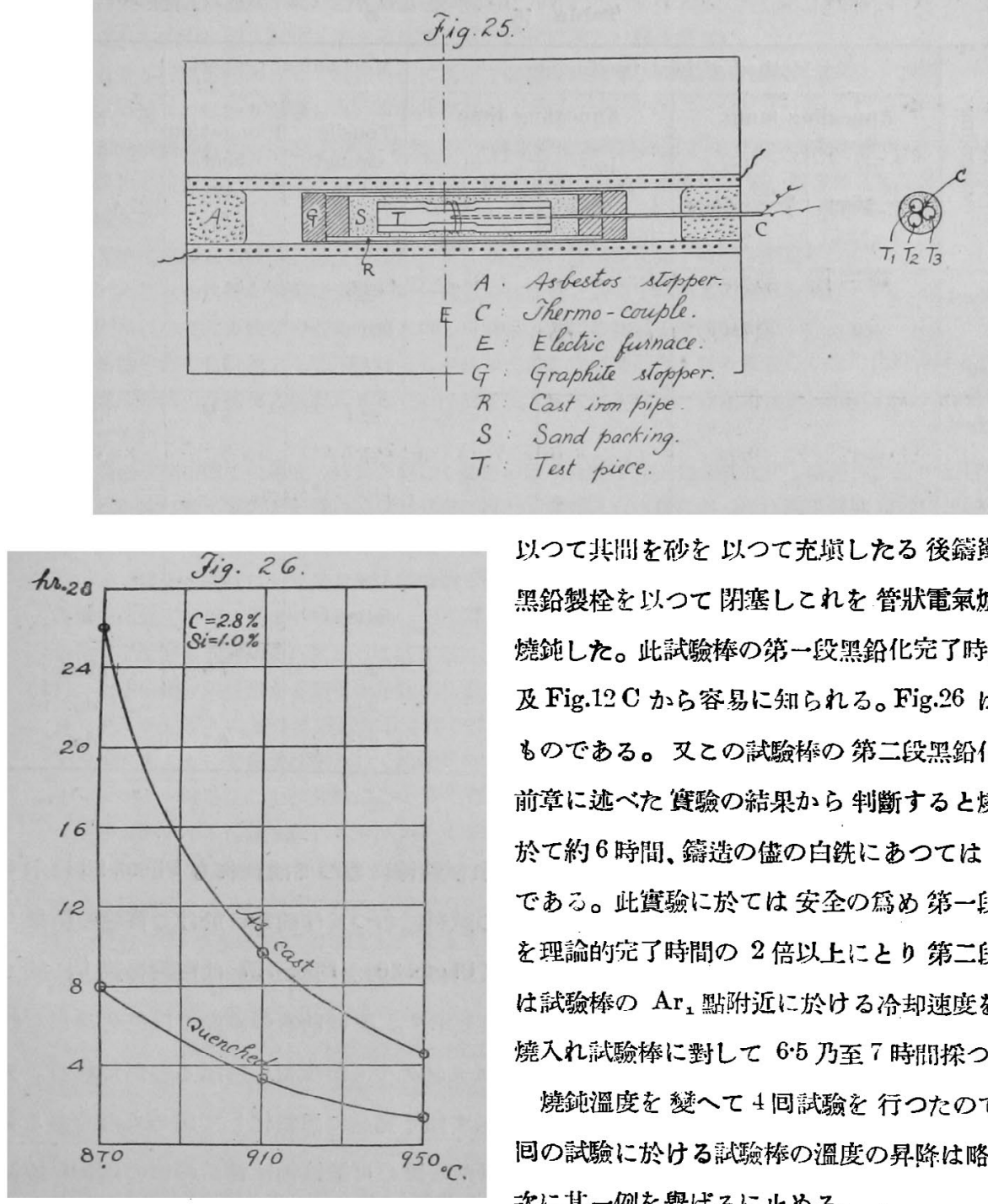

以つて其临を砂を以つて克埪したる後篟戴管の兩端を 墨鉛製柽を以って閉塞してれを管狀電氣㠊內に入れて

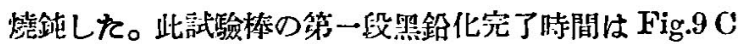
及Fig.12C から容易に知られる。Fig.26 はてれを示す

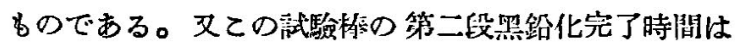

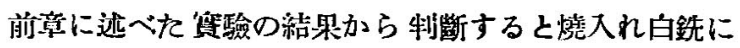

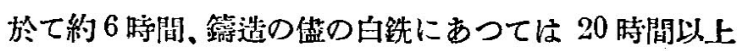

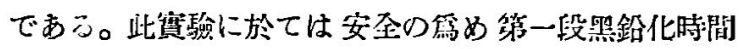

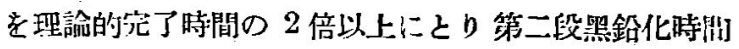

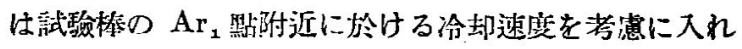
燒入れ武驗棒に對して 6.5 乃至 7 時間探つた。

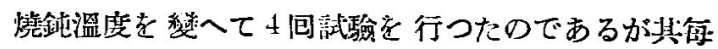

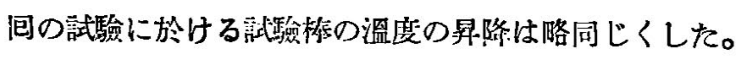
次に其一例走㦛げるに止める。

Experiment No.2

室溫 $740^{\circ} \mathrm{C} \longleftarrow(7.5$ 時間保持 $) \longrightarrow 740^{\circ} \mathrm{C} \longleftarrow 3$ 時間 $\longrightarrow 450^{\circ} \mathrm{C}$

各試驗に於ける燒鈍溫度及燒鈍時閵は Table 16 に示してある。

實驗の結果 : 一一實憸の結果は Table 16 に示す如くである。實驗番號 1 に於ては此較の篇めに同

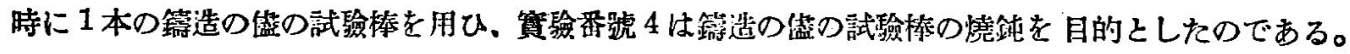

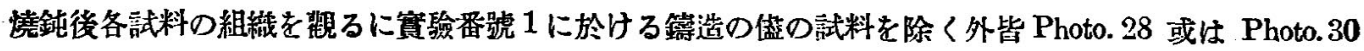


Table 16

\begin{tabular}{|c|c|c|c|c|c|c|c|c|}
\hline \multirow{3}{*}{ 若 } & \multirow{3}{*}{ 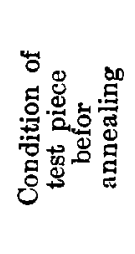 } & \multicolumn{4}{|c|}{ Method of heat treatment } & \multicolumn{2}{|c|}{ Mechanical property } & \multirow{3}{*}{ 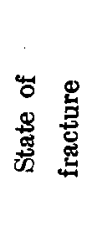 } \\
\hline & & \multicolumn{2}{|c|}{ Annealing temp. } & \multicolumn{2}{|c|}{ Annealing time } & \multirow{2}{*}{$\begin{array}{l}\text { Tensile } \\
\text { strength } \\
\text { in } \\
\text { ton } / \bar{c}^{\prime \prime}\end{array}$} & \multirow[b]{2}{*}{\begin{tabular}{|} 
Elongation \\
$(5 \mathrm{~cm})$ \\
in \\
$\%$
\end{tabular}} & \\
\hline & & $\begin{array}{l}\text { in } \\
1 \frac{\text { st }}{{ }^{\prime}} \text { stage } \\
\left.{ }^{\circ} \mathrm{C}\right)\end{array}$ & 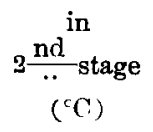 & $\begin{array}{l}\text { in }_{\text {st }} \\
1-{ }_{-} \text {-stage } \\
\text { hr. - min. }\end{array}$ & 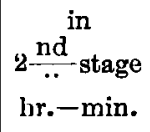 & & & \\
\hline 1 & $\begin{array}{l}\text { Quenched } \\
\text { do. } \\
\text { As cast }\end{array}$ & seo & 740 & 30 & 30 & $\begin{array}{l}21 \cdot 5 \\
\text { failed (*) } \\
24: 6\end{array}$ & $5 \cdot 8$ & $\begin{array}{l}\text { black } \\
\text { ditto } \\
\text { white }\end{array}$ \\
\hline 2 & $\begin{array}{l}\text { Quenched } \\
\text { do. } \\
\text { do. }\end{array}$ & 800 & $7 ! 0$ & 10 & 30 & $\begin{array}{l}22 \cdot 4 \\
21 \cdot 7(*) \\
\text { failed }(*)\end{array}$ & $\begin{aligned} & 5 \cdot 7 \\
> & 5\end{aligned}$ & $\begin{array}{l}\text { black } \\
\text { do. } \\
\text { do. }\end{array}$ \\
\hline 3 & $\begin{array}{l}\text { Quenched } \\
\text { do. } \\
\text { do. }\end{array}$ & 870 & 740 & 15 & 30 & $\begin{array}{l}25 \cdot 3 \\
23 \cdot 1 \\
\text { failed (*) }\end{array}$ & $\begin{array}{l}5 \cdot 8 \\
5 \cdot 2\end{array}$ & $\begin{array}{l}\text { black } \\
\text { do. } \\
\text { do. }\end{array}$ \\
\hline 4 & $\begin{array}{l}\text { As cast } \\
\text { do. } \\
\text { Quenched }\end{array}$ & 910 & 740 & 19 & 11 & $\begin{array}{l}20 \cdot 7 \\
20 \cdot 4 \\
22 \cdot 9\end{array}$ & $\begin{array}{l}7 \cdot 5 \\
7 \cdot 5 \\
5 \cdot 7\end{array}$ & $\begin{array}{c}\text { black } \\
\text { do. } \\
\text { do. }\end{array}$ \\
\hline
\end{tabular}

(*) 標黙外切断

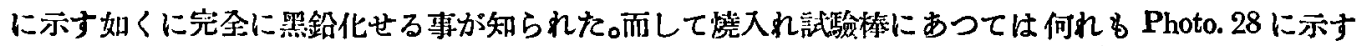

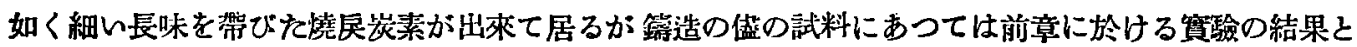

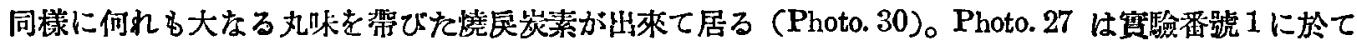

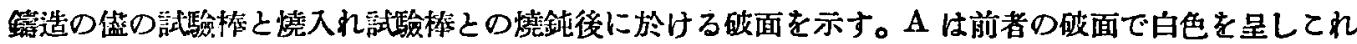
を影微鏡で見るに Photo. 29 に示す如く晌多量の遊離セメンタイトが殘留して居るのが知れる。又 B注後者の破面で黑色を呈して居る。てれは Photo. 28 に示す如く完全に黑鉛化して居るるのである。

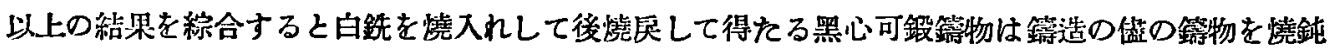
したるものに比でて抗張力に於て遙に倀るが延伸率に於て少しく劣る事が知られる。 此賽驗に用ひた陚料を同一成分の白鉄を實地工場にて燒鈍すれば Fig. 23 から知られる如く其执張 力は約 21.5 ton/の"で延伸率は約 $9 \%$ となり。乙れを本實驗の結果に比して.も知張り上と同樣の關係 が認められるのである。此原因は恐らく燒鈍の際に生する燒杘炭素の大さ及形狀に因るもので試驗棒 の含炭量がより小なれば其延伸率も大に改䇺されるは想倸に難くない。

總括

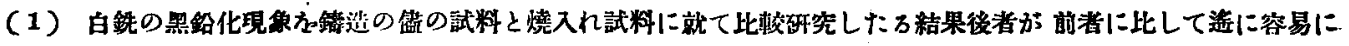
黑鉛化す万事定方見した。 


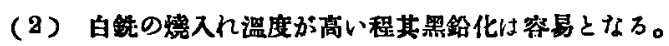

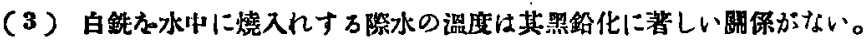

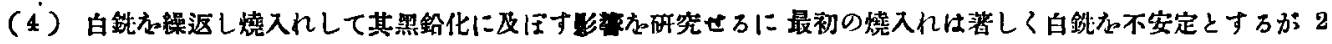

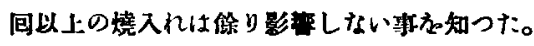

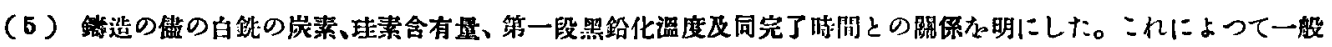

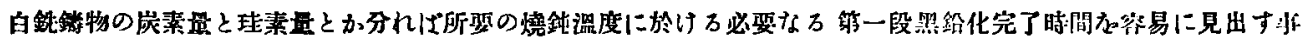
が出來ら。

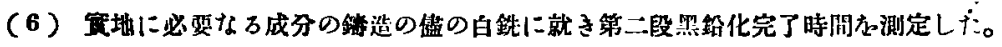

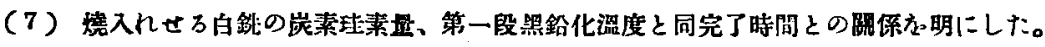

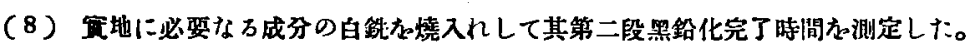

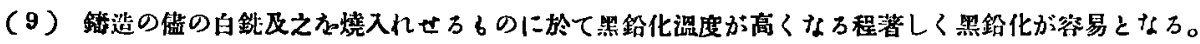

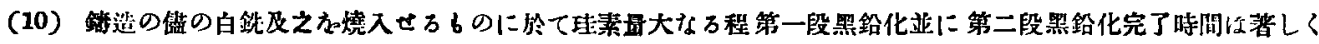
经糖せ5れる。

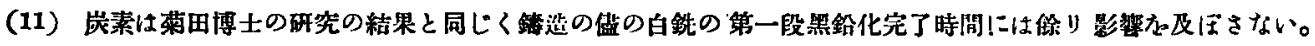

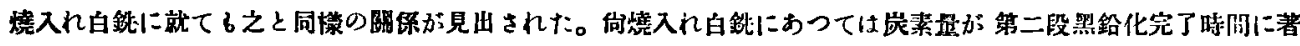

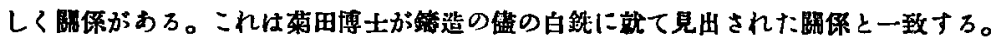

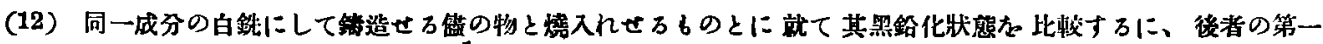

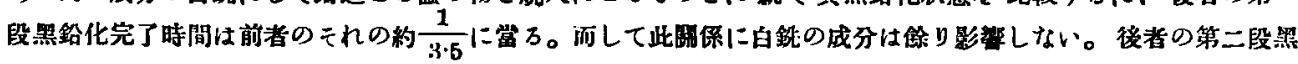

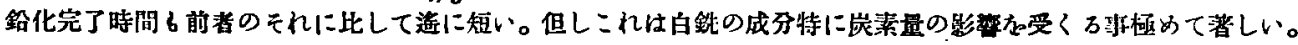

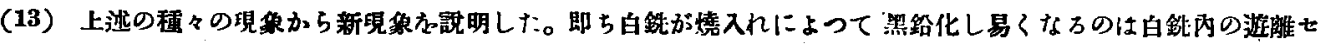

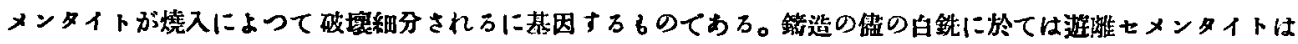

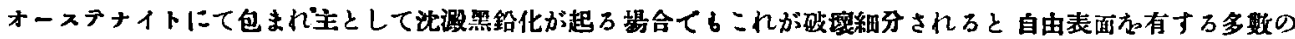

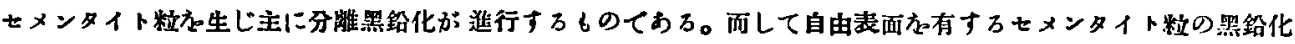

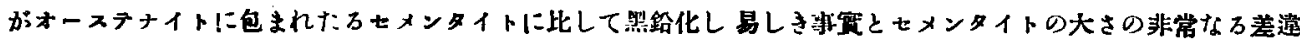

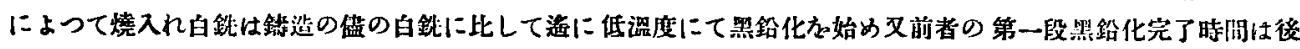
者のこれに比して粪に短樎されるるのておる。

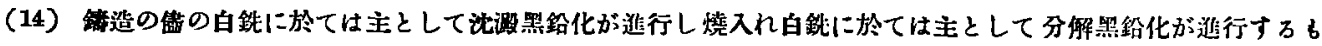
のてあるが故に、後者の第一段黑鉛化に與る遊雕もメンタイトの量は前替のそれに比して迷に多い。換言すれば

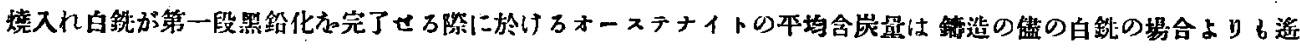

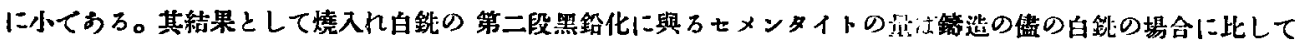

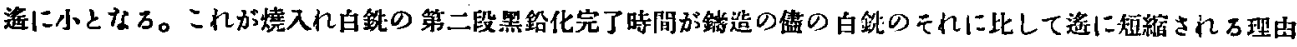
てある。

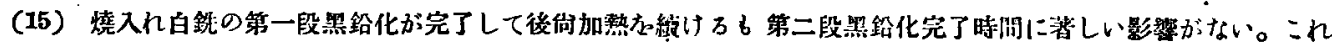

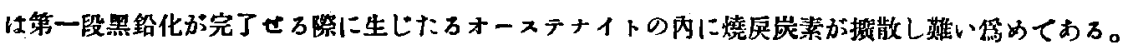

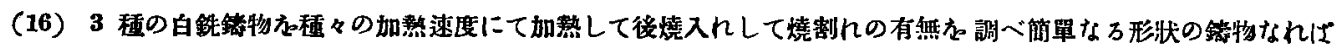

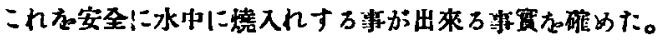

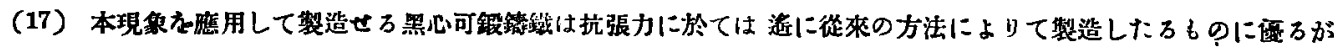

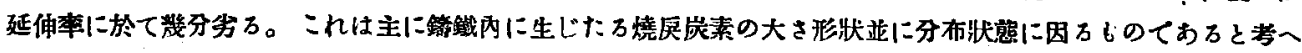
$5 れ る 。$

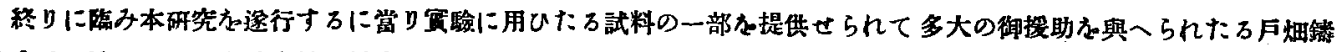

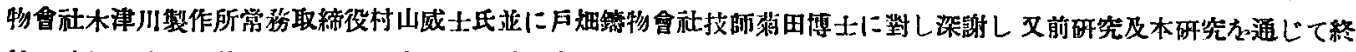
始正磪なる分析の労㤂勃られたる幸田軍一氏に多解す。 


\section{文献}

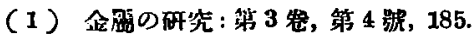

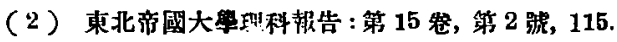

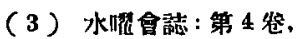

第 5 蹠, 703; 第 6 號, 929; 第 7 號. 1147;

讶 8 號, 1195; 第 9 胧, 1355.

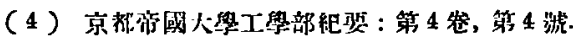

(5) J. Iron Stcel Inst.:(1919) No. 2. 417.

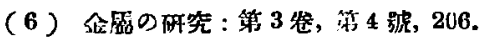

(7) 践と銓: 第111年 12 號, 891 。

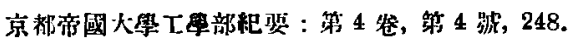

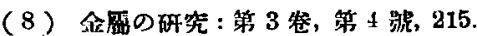

\section{含銅鋼の表面疵に就て}

On the Surface Defect of the Copper-bearing Steel.

\section{大石 源 治}

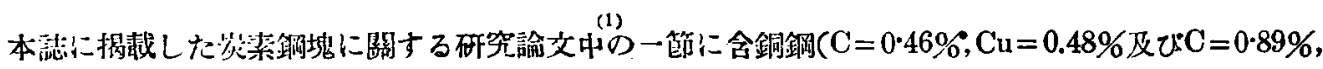

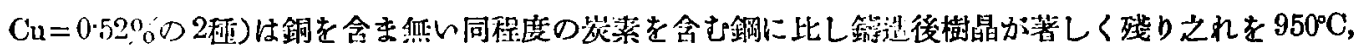
$1,100^{\circ} \mathrm{C}, 1,200^{\circ} \mathrm{C}$ 等D溫度で燒鈍するに $950^{\circ} \mathrm{C}$ では 30 時間䍌鈍しても多少樹晶の殘る試料があるが

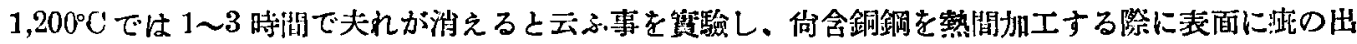

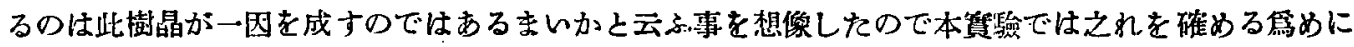

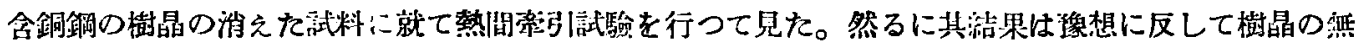

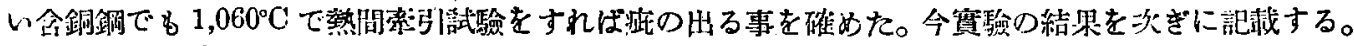
武料は前に本誌に提载したものと同じ战分で次を゙の栐なものを用るた。

$\begin{array}{cccccc} & \mathrm{C} & \mathrm{Cu} & \mathrm{Cr} & \mathrm{Si} & \text { Mn } \\ & \% & \% & \% & \% & \% \\ \mathrm{~A} & \mathbf{6 6} & - & - & 0.52 & 0.50 \\ \mathrm{~B} & \mathbf{0 . 4 6} & 0.48 & - & 0.61 & 0.43 \\ \mathrm{C} & 0.43 & - & 0.53 & 0.56 & 0.45\end{array}$

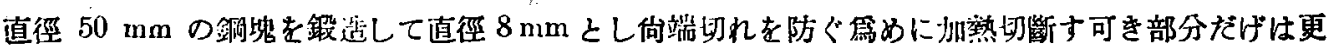

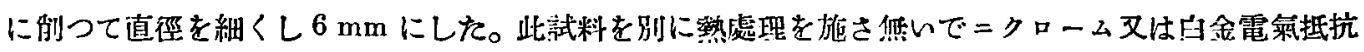

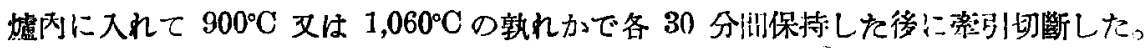

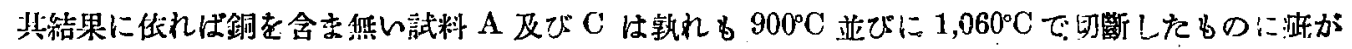

